\title{
Using Remotely Sensed Imagery and GIS to Monitor and Research Salmon Spawning: A Case Study of the Hanford Reach Fall Chinook (Oncorhynchus Tshawytscha)
}

R. H. Visser

March 2000

Prepared for

the U.S. Department of Energy

under Contract DE-AC06-76RLO 1830

Pacific Northwest National Laboratory

Richland, Washington 99352 
-

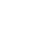




\section{DISCLAIMER}

This report was prepared as an account of work sponsored by an agency of the United States Government. Neither the United States Government nor any agency thereof, nor any of their employees, make any warranty, express or implied, or assumes any legal liability or responsibility for the accuracy, completeness, or usefulness of any information, apparatus, product, or process disclosed, or represents that its use would not infringe privately owned rights. Reference herein to any specific commercial product, process, or service by trade name, trademark, manufacturer, or otherwise does not necessarily constitute or imply its endorsement, recommendation, or favoring by the United States Government or any agency thereof. The views and opinions of authors expressed herein do not necessarily state or reflect those of the United States Government or any agency thereof. 


\section{DISCLAIMER}

Portions of this document may be illegible in electronic image products. Images are produced from the best available original document. 


\section{Summary}

Current monitoring techniques for fall chinook salmon (Oncorhynchus tshawytscha) populations in the Hanford Reach of the Columbia River provide estimates of salmon escapement and spawning activity. However, these methods often do not provide the level of detail needed by fisheries managers to evaluate habitat use or to quantify changes within spawning sites. This report describes a methodology for quantifying redd characteristics using aerial photography and a Geographic Information System (GIS). The study goal was to determine if this methodology could enhance current monitoring capabilities. The specific objective of the study was to determine if redd characteristics (number, size, density, and spatial distribution) could be better quantified.

Individual fall chinook redds were digitized from aerial photographs into a GIS and then quantified, mapped, and analyzed. Results were compared to aerial survey redd counts and estimated escapement (a count of adult salmon that pass over dams into a particular stretch of river) to determine if GIS-based analysis would support and improve monitoring techniques currently used in the Hanford Reach.

Peak redd counts based on aerial photography and GIS analyses reflected escapement estimates and were $40 \%$ higher than aerial survey redd counts. The mean redd size was $21.2 \mathrm{~m}$ (range 7.5 to $61.8 \mathrm{~m}$ ). Redd density ranged from 32 to 84 redds per ha. Spatial distribution of redds at peak spawning exhibited an even distribution. Carrying capacity of the Hanford Reach, based on spatial metrics obtained from GIS analyses, was estimated to be between 74,000 and 90,000 adult fall chinook. Aerial photography with GIS analyses were effective tools for monitoring and quantifying spawning activity and habitat use of fall chinook salmon. 
- 


\section{Contents}

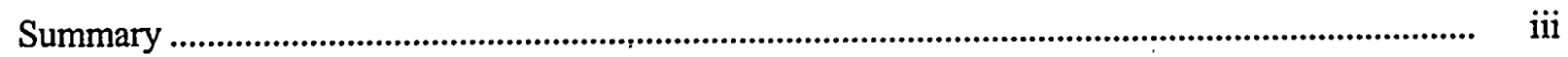

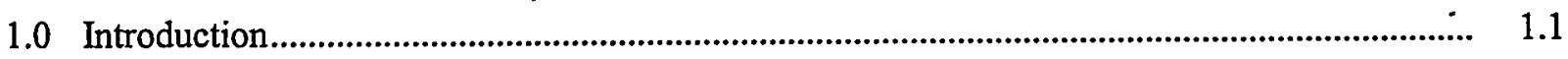

1.1 Background.............................................................................................................. 1.2

1.2 Objectives .............................................................................................................

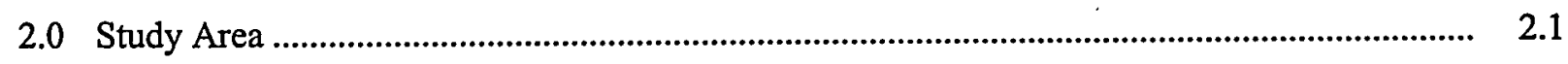

2.1 Physical Setting ....................................................................................................... 2.1

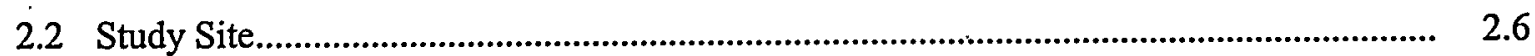

3.0 Methods ................................................................................................................... 3.1

3.1 Redd Construction ............................................................................................................. 3.1

3.2 Photography and Image Analyses ......................................................................... 3.2

3.3 Redd Characteristics ................................................................................................... 3.4

3.3.1 Redd Counts, Ratio to Female Escapement, and Density......................................... 3.4

3.3.2 Redd Size and Area Disturbed Per Cluster.................................................................. 3.6

3.3.3 Redd Spatial Analysis.................................................................................................... 3.7

3.4 Estimating Spawner Carrying Capacity .......................................................................... 3.8

3.5 GIS Analyses Versus Aerial Surveys and Dam Counts ................................................. 3.8

3.6 Identifying Key Index Sites ......................................................................................... 3.9

4.0 Results......................................................................................................................

4.1 Redd Characteristics ..................................................................................................... 4.1

4.1.1 Redd Counts, Ratio to Female Escapement, and Density....................................... 4.1

4.1.2 Redd Size and Area Disturbed Per Redd Cluster .................................................... 4.3

4.1.3 Redd Spatial Analyses .......................................................................................... 4.5

4.2 Estimating Spawner Carrying Capacity........................................................................ 4.9

4.3 GIS Analyses Versus Aerial Surveys and Dam Counts .................................................... 4.10

4.4 Identifying Key Index Sites....................................................................................... 4.12 


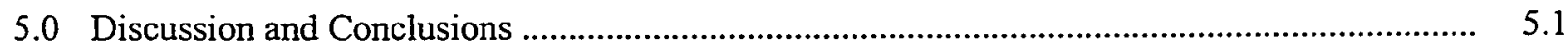

5.1 Redd Counts, Habitat Identification and Mapping, and Density Measurements............... 5.1

5.2 Spatial Characteristics and their Relationships to Density and Carrying Capacity ........... 5.3

5.3 GIS Analyses Compared to Aerial Surveys and Dam Counts.................................... 5.5

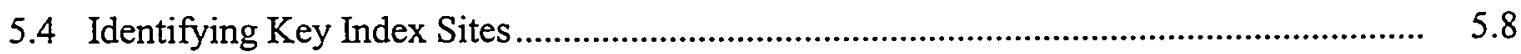

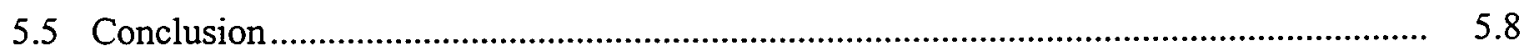

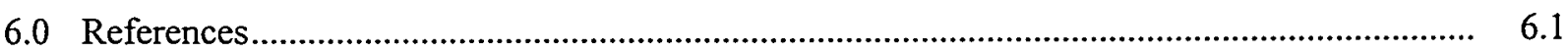




\section{Figures}

1 The Hanford Reach, Located in Southeastern Washington ......................................................... 1.1

2 The Hanford Reach of the Columbia River ............................................................................ 2.2

3 The White Bluffs ............................................................................................................... 2.3

4 Historical Change in Seasonal Flow Patterns in the Hanford Reach During Fall Chinook Salmon Spawning ........................................................................................................... 2.4

5 Example of Daily Flow Variation in the Hanford Reach During Fall Chinook Spawning........ 2.5

6 Aerial Photograph Exhibiting Some of the Channel Complexity Found in the Hanford Reach of the Columbia River.......................................................................................................... 2.5

$7 \quad$ Study Site Within the Hanford Reach........................................................................................... 2.7

8 Line Drawing of a Female Salmon Disturbing the Substrate While Constructing a Redd........ 3.1

9 Scanned Color Aerial Photograph Showing Visible Redds in Cluster 4B................................. 3.3

10 The Hanford Reach in Relation to McNary, Ice Harbor, and Priest Rapids Dams, the Priest Rapids Hatchery, and the Yakima River ................................................................................... 3.6

11 Nearest Neighbor Distance was Measured from the Center Point of a Redd to the Center Point of its Nearest Neighbor.

12 Relative Proportion of Redds Per Defined Redd Cluster in the Hanford Reach for 1991, 1994, and 1995

13 Relative Proportion of Redds Counted Per River Kilometer in the Hanford Reach for 1991, 1994, and 1995

14 Proportion of the Total Area Disturbed in Each Redd Cluster in the Hanford Reach During 1994 and 1995.

15 Total Area Disturbed in Each Redd Cluster in the Hanford Reach During 1994 and 1995 ...... 4.6

16 R-Values Calculated Using GIS Analyses for Each Redd Cluster in the Hanford Reach During 1994 and 1995

17 The Relationship Between Redd Density and Redd Size Within the Study Site During 1994 and 1995

18 The Relationship Between Redd Density and Distance to Nearest Neighbor Within the Study Site During 1994 and 1995 
19 The Relationship Between Redd Density and R-Values Within the Study Site During 1994 and 1995

20 Percentage of Redds that Each Area Contributed to the Total Redd Count in the Study Site for 1991, 1994, and 1995

21 The Number of Redds Counted Per Area in the Hanford Reach During 1991 Using Aerial Photographs with GIS Analyses Versus the Number of Redds Counted Using an Aerial Survey

22 Redd Counts Over Time During 1994 and 1995 Using Aerial Photographs With GIS Analyses and Aerial Surveys in the Hanford Reach Study Site.

23 A Comparison Between GIS and Aerial Survey Redd Counts Over Time in Areas 2, 3, 4, 5 , and 7 in the Hanford Reach Study Site During 1994

24 A Comparison Between GIS and Aerial Survey Redd Counts Over Time in Areas 2, 3, 4, 5, and 7 in the Hanford Reach Study Site During 1995

25 A Comparison Between the Number of Redds Counted With GIS Analyses and Aerial Redd Surveys Within the Hanford Reach Study Site and the Estimated Female Fall Chinook Salmon Escapement into the Hanford Reach for 1991, 1994, and 1995

\section{Tables}

1 Redd Clusters Found Within Designated Areas Defined by Dauble and Watson

2 Redd Counts Based on Aerial Photographs and GIS Analyses for Defined Redd Clusters in the Hanford Reach for 1991, 1994, and 1995

3 Density of Redds Based on Aerial Photographs and GIS Analyses for Each Redd Cluster in the Hanford Reach for 1994 and 1995

$4 \quad$ Redd Size Measured Using Aerial Photography and GIS Analyses for Each Redd Cluster in the Hanford Reach During 1994 and 1995

5 Mean Nearest Neighbor Distance Measured with GIS Analyses for Each Redd Cluster in the Hanford Reach During 1994 and 1995

6 Number of Redds Counted as a Percentage of the Estimated Female Escapement for Each Area and Redd Cluster With the Coefficient of Variation Between 1994 and 1995 


\subsection{Introduction}

The alteration of ecological systems has greatly reduced salmon populations in the Pacific Northwest. The Hanford Reach of the Columbia River (Figure 1), for example, is a component of the last ecosystem in eastern Washington State that supports a relatively healthy population of fall chinook salmon ([Oncorhynchus tshawytscha], Huntington et al. 1996). This population of fall chinook may function as a metapopulaton for the Mid-Columbia region (ISG 1996). Metapopulations can seed or re-colonize unused habitat through the mechanism of straying (spawning in non-natal areas) and may be critical to the salmon recovery process if lost or degraded habitat is restored (i.e., the Snake, Upper Columbia, and Yakima rivers). For these reasons, the Hanford Reach fall chinook salmon population is extremely important for preservation of the species in the Columbia River Basin. Because this population is important to the region, non-intrusive techniques of analysis are essential for researching and monitoring population trends and spawning activities.

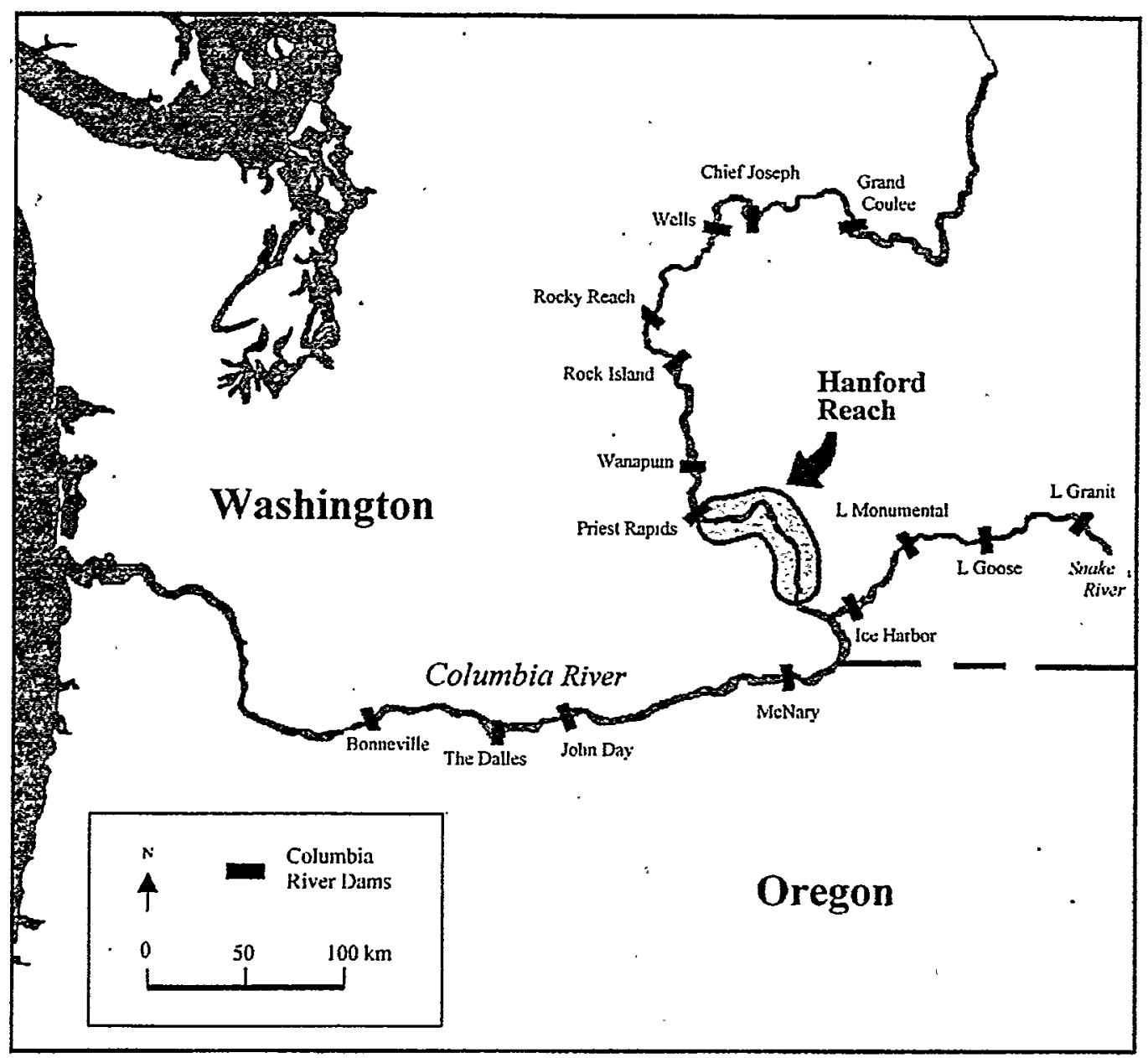

Figure 1. The Hanford Reach, Located in Southeastern Washington. This section of the Columbia River begins below Priest Rapids Dam and ends at the backwaters of McNary Dam. 
Currently, non-intrusive techniques provide limited monitoring and mapping capabilities and only minor quantifiable data sets for spatial analysis. This report describes and tests a new methodology for monitoring fall chinook spawning in the Hanford Reach using aerial photography in conjunction with Geographic Information System (GIS) technology.

\subsection{Background}

Monitoring salmon populations and spawning activity in the mainstem Columbia River has a long history. Salmon have been counted as they pass over dams to estimate escapement since 1938 (WDFW and ODFW 1992). Escapement into the Hanford Reach has been estimated since 1962 (Chris Carlson, Grant County Public Utility District, personal communication 1996). In addition, spawning activity has been monitored for more than 50 years using aerial surveys or counting redds from a low-flying plane (Dauble and Watson 1997). These types of surveys provide useful information for fisheries managers. For example, monitoring yearly adult returns can help managers determine how fish respond to natural processes (such as harvest, predation, competition for limited resources, and disease) and to manmade obstructions (such as dams, water diversions, and pollution). The number of returning spawners can also be used to monitor population trends, predict future population sizes, and measure the effectiveness of management strategies and actions.

Specific techniques that have been used to monitor and map spawning habitat in the Hanford Reach include aerial surveys (Dauble and Watson 1997) and SCUBA diving surveys (Swan 1989). Dauble and Watson (1997) have identified general locations of redds within defined areas annually, while Swan (1989) used SCUBA divers and survey equipment to map specific locations of redds found in deep water. Aerial surveys are effective for monitoring shallow water spawning (less than $4 \mathrm{~m}$ ) in general locations. However, they cannot monitor deep-water spawning or precisely map spawning habitat. SCUBA diving and underwater surveying equipment can be used to detect spawning habitat in deep water, although this technique is not practical for routine monitoring because of relatively low efficiency and safety concerns. Identifying and mapping spawning habitat and use are critical for managers to study fall chinook spawning and to argue more effectively for protection if any actions threaten to destroy or reduce productivity.

Researchers typically use three main variables to define spawning habitat characteristics for fall chinook salmon in the mainstem Columbia and Snake rivers: 1) substrate size, 2) water depth, and 3) water velocity (Chapman 1943; Chapman et al. 1983; Swan 1989; Giorgi 1992; Conner et al. 1993; Dauble et al. 1995; Geist et al. 1997). These three variables have also been used to develop the Physical Habitat Simulation Model (Milhous 1979; Stalnaker 1979), which attempts to predict available spawning habitat. However, Geist et al. (1997) found that this model may overestimate the amount of suitable spawning habitat and suggested that other variables, such as groundwater upwelling, be included in the model. More precise mapping of spawning grounds may help researchers identify other variables associated with suitable spawning habitat through application of sophisticated pattern recognition methodologies.

GIS technology has only recently been used to evaluate salmon habitat. Lunetta et al. (1997) used GIS analyses to predict locations of river and stream response reaches likely to provide salmon habitat in the Pacific Northwest. Geist and Dauble (1998) used GIS spatial data to evaluate geomorphic features 
that influence spawning locations in reaches of large rivers. Dauble et al. (1995) used GIS, in conjunction with underwater video and Global Positioning System (GPS) technologies to identify and map redd locations downstream of dams on the Snake River. GIS and remote sensing technologies can enhance current monitoring and research capabilities through enhanced spatial processing and pattern recognition.

Currently, two monitoring techniques are used annually to count and evaluate population trends of fall chinook salmon that spawn in the Hanford Reach. Estimated escapement, counting adult passage over dams, is currently the best method for monitoring the number of salmon that enter a particular river section. Aerial surveys are effective for monitoring shallow-water spawning and have been shown to reflect escapement estimates relatively well (Dauble and Watson 1997). Although these monitoring techniques have provided yearly estimates of salmon population and general spawning locations, their accuracy and use are limited. In their evaluation of fall chinook spawning in the Hanford Reach, Dauble and Watson (1990) listed several research needs for effective management of fall chinook salmon production. Improved methods for documenting the location and extent of spawning areas, characterizing habitat requirements, and determining production potential are a few of the needs they listed. Using aerial photography in conjunction with GIS to monitor and research fall chinook spawning may address these needs.

\subsection{Objectives}

The objectives of this study were to: 1) develop a means to digitize and map redds and their locations, 2) measure redd characteristics and identify distribution patterns, 3) identify redd density relationships, 4) estimate the carrying capacity of spawning grounds in the Hanford Reach based on spatial findings, 5) compare the effectiveness of using remote sensing and GIS technology versus other moni- . toring techniques, and 6) identify possible index sites for future monitoring. Meeting these objectives will demonstrate the monitoring technique's use, increase our understanding of fall chinook spawning interactions and needs, and provide useful information for managers regarding fall chinook that spawn in the Hanford Reach. 


\subsection{Study Area}

This section describes the physical setting and history of the Hanford Reach and the specific area used to conduct this study.

\subsection{Physical Setting}

The Hanford Reach of the Columbia River is located in southeastern Washington and flows approximately 90 kilometers from Priest Rapids Dam (rkm 639) to the slack waters of the McNary Dam Reservoir near the city of Richland. This stretch of the Columbia River has been commonly referred to as the last "free-flowing" segment of the river upstream of Bonneville Dam within the United States. However, "free-flowing" is not a truly accurate description of the Hanford Reach because it is highly regulated by water releases from upstream dams. that are largely operated for power generation and irrigation diversion. The river flows through and along the Hanford Site, Wahluke Slope Wildlife Area (managed by the Washington Department of Fish and Wildlife), Saddle Mountain National Wildlife Refuge (managed by the U.S. Fish and Wildlife Service), and other state and privately owned lands (Figure 2).

The Reach's undammed status is largely due to the history and proximity of the Hanford Site on the southwest shoreline and a buffer zone (the Wahluke Slope Wildlife Area and the Saddle Mountain National Wildlife Refuge) on the northeast shoreline. This buffer zone was established for safety and security reasons when nuclear processing began in the 1940s, and in recent times, has been mostly managed for wildlife use. Management of the Hanford Site and its buffer zones has prevented hydropower, agricultural, and industrial development within a large proportion of the Hanford Reach. This exclusion of development, except for nuclear processing, has preserved much of the natural ecosystem that surrounds and protects a large portion of the Hanford Reach. In addition to supporting the spawning grounds of fall chinook salmon, the preservation of this area also supports several native, but at risk, terrestrial plants and animals (Rickard and Poole 1989; Fitzner and Gray 1991).

The geological setting of the Hanford Reach is one that was formed by two large geological processes: massive basaltic lava flows and sediment erosion and deposition, particularly by the Bretz Floods. The basaltic flows took place over several million years, originating from fissures east of the area that laid layer upon layer of basalt on top of one another 17-6 million years ago. These events built the Columbia Basalt Plateau, one of the world's largest accumulations of basaltic lava flows (covering more than $160,000 \mathrm{~km}^{2}$ ). The most recent of these flows, the Yakima Basalt Formation, is the top layer of many uplifted mountains and ridges that surround the Hanford Reach, including Rattlesnake Mountain, Yakima Ridge, Umtanum Ridge, Gable Butte, Gable Mountain, and the Saddle Mountains.

The area accumulated several layers of fluvial, lacustrine, and glaciofluvial sediments (Dresel et al. 1995) before the next major geological process. Included in these layers is the Ringold Formation, which was formed by river and lake sediments deposited between 1 and 2 million years ago. After millions of years of erosion and deposition, the Bretz Floods (a series of catastrophic floods) transformed the 


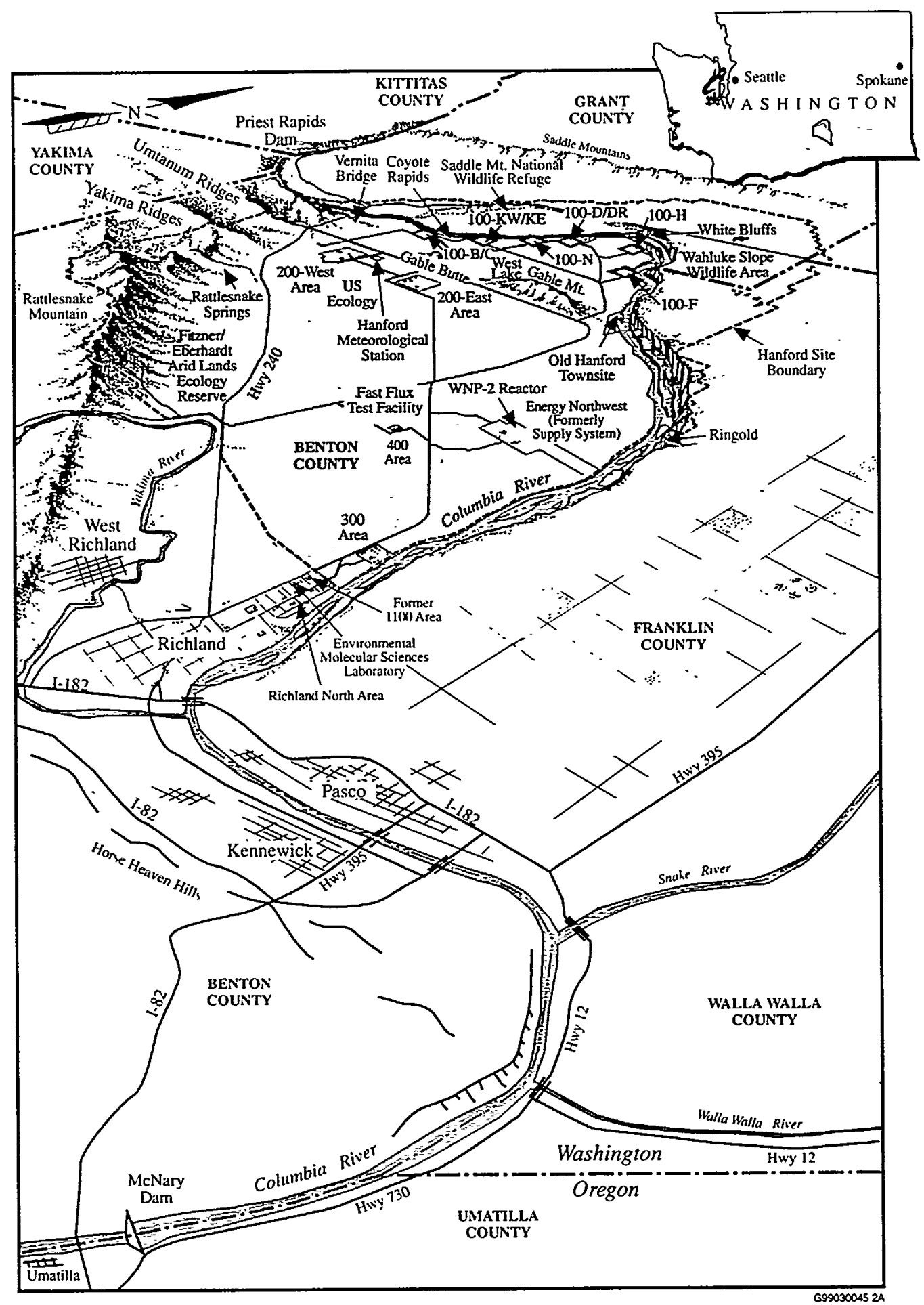

Figure 2. The Hanford Reach of the Columbia River. The Reach flows through the U.S. Department of Energy's Hanford Site. Three land divisions buffer the Site's core: the Saddle Mountain National Wildlife Refuge, the Wahluke Slope Wildlife Area, and the Fitzner/Eberhardt Arid Lands Ecology Reserve (Dirkes et al. 1999). 
landscape of the Columbia Basin, including the land surrounding the Hanford Reach. These floods occurred between 100,000 and 12,000 years ago and were initiated by repeated failures of ice dams that retained and released large quantities of water stored in prehistoric Lake Missoula. These floods scoured large volumes of fluvial and laucstrine deposits and chunks of basaltic bedrock throughout eastern Washington, including the study area. These floods also deposited massive volumes of materials ranging in size from boulders to fine silts, including gravels that provide today's fall chinook salmon spawning beds.

Vertical and lateral erosion by the Columbia River exposed and formed șteep 45 to $170 \mathrm{~m}$ bluffs (Figure 3) known today as the White Bluffs (Schuster and Hays 1984). The White Bluffs consist of claystones, siltstones, and sandstones that are susceptible to mass wasting events when saturated. There are many signs of prehistoric slides, indicating that past climatic conditions were wet enough to cause mass wasting events, but today's climate is too dry to sustain the ground moisture needed to initiate slides. However, recent irrigation in the Columbia Basin Irrigation Project (lands to the north and east of the Bluffs) has reinitiated some of the landsliding (Schuster and Hays 1984). A continuation or increase of White Bluff mass wàsting may have serious negative impacts if fine sediments are deposited within fall chinook spawning grounds. Fine sediment deposition can suffocate and entomb salmon eggs and increase the embeddedness of the substrate, making it unsuitable for spawning.

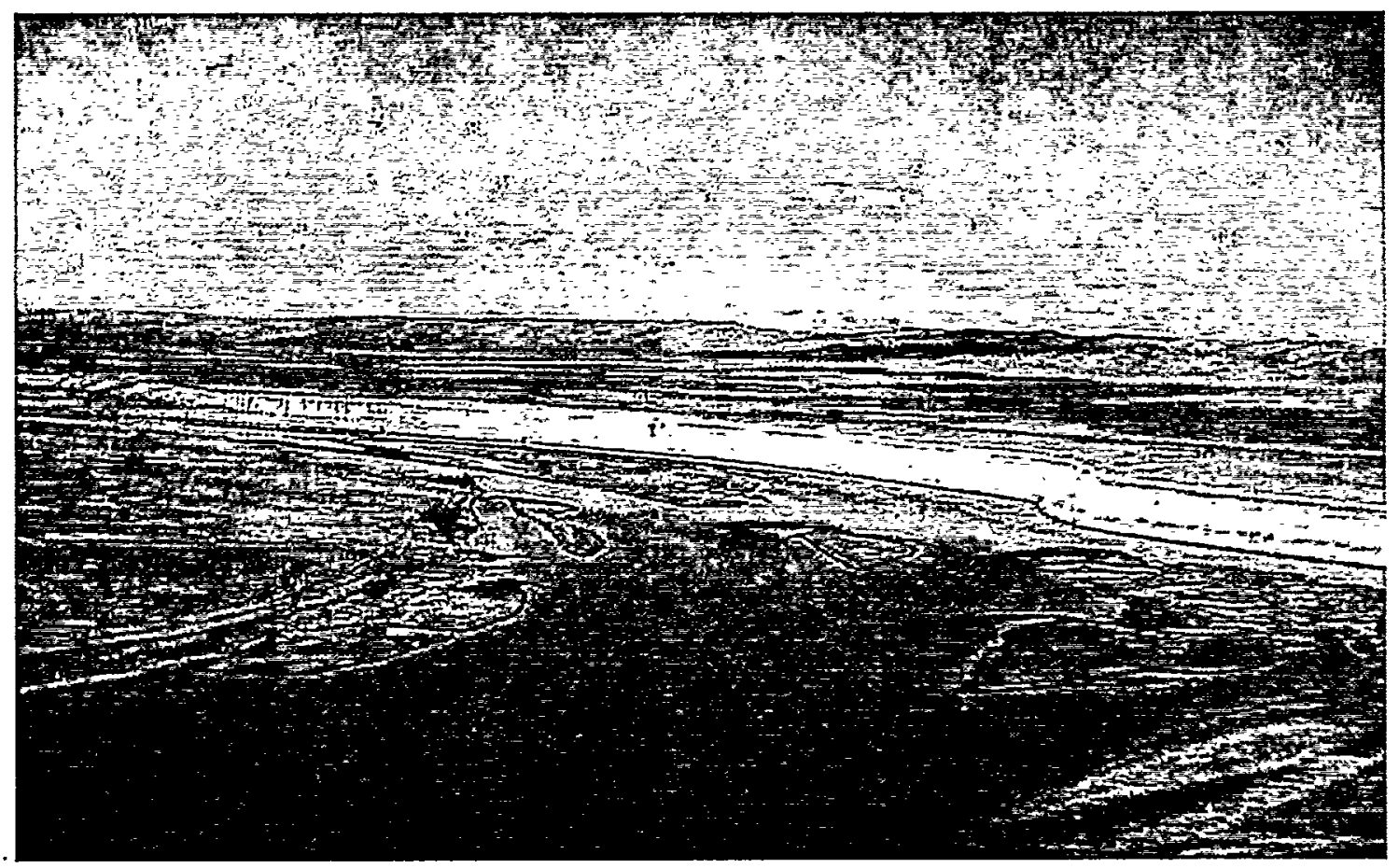

Figure 3. The White Bluffs. The bluffs are a geologic formation that consists of claystones, siltstones, and sandstones that become susceptible to mass wasting when saturated. 
The Hanford Reach is the only major water body from Priest Rapids Dam to the slack waters of McNary Reservoir. Several irrigation return ditches occur on the eastern shoreline of the Hanford Reach that could impact water quality and spawning grounds (i.e., delivery of fine sediment). The return ditches are near the White Bluffs boat launch ( $\mathrm{kkm} 629$ ), Ringold hatchery ( $\mathrm{rkm} \mathrm{572)}$ ), and in north Richland ( $\mathrm{rkm}$ 553). Managing the Columbia River for energy production and irrigation has altered the Hanford Reach's seasonal, weekly, and daily hydraulic patterns from historic conditions. Seasonal discharge patterns have been altered to correspond to energy and irrigation needs. Average discharge to the Hanford Reach in the fall appears to have increased (Figure 4), while variation in weekly and daily.flows have also increased substantially from the pre-dam period (Figure 5) (Dauble and Watson 1997). These hydraulic changes impact both spawning and rearing salmon and influence the visibility of redds from the air so flow patterns must be considered when planning flights for aerial surveys and aerial photographs.

The geomorphology of the Hanford Reach has structural complexity that provides essential spawning and rearing habitat for fall chinook. Over this $90 \mathrm{~km}$ stretch, the river drops approximately $18 \mathrm{~m}$ $(0.2 \mathrm{~m} / \mathrm{km})$, and its channel width ranges from 150 to $600 \mathrm{~m}$. Physical features of the river channel and its floodplain are diverse. The channel depth ranges from $<1 \mathrm{~m}$ in rapids to $\geq 20 \mathrm{~m}$ in deep pools. There
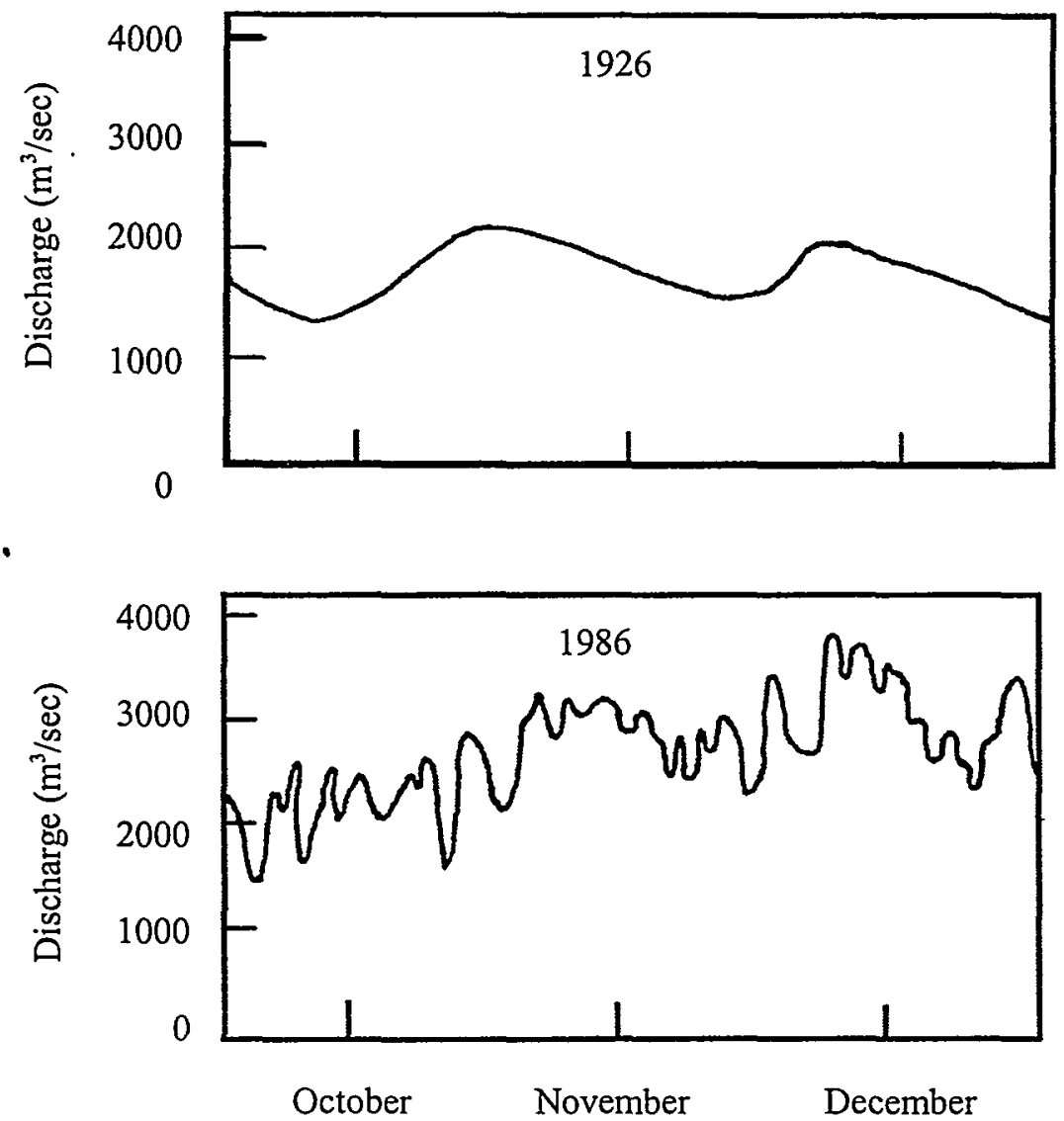

Figure 4. Historical Change in Seasonal Flow Patterns in the Hanford Reach During Fall Chinook Salmon Spawning (average daily discharge from Priest Rapids Dam) 


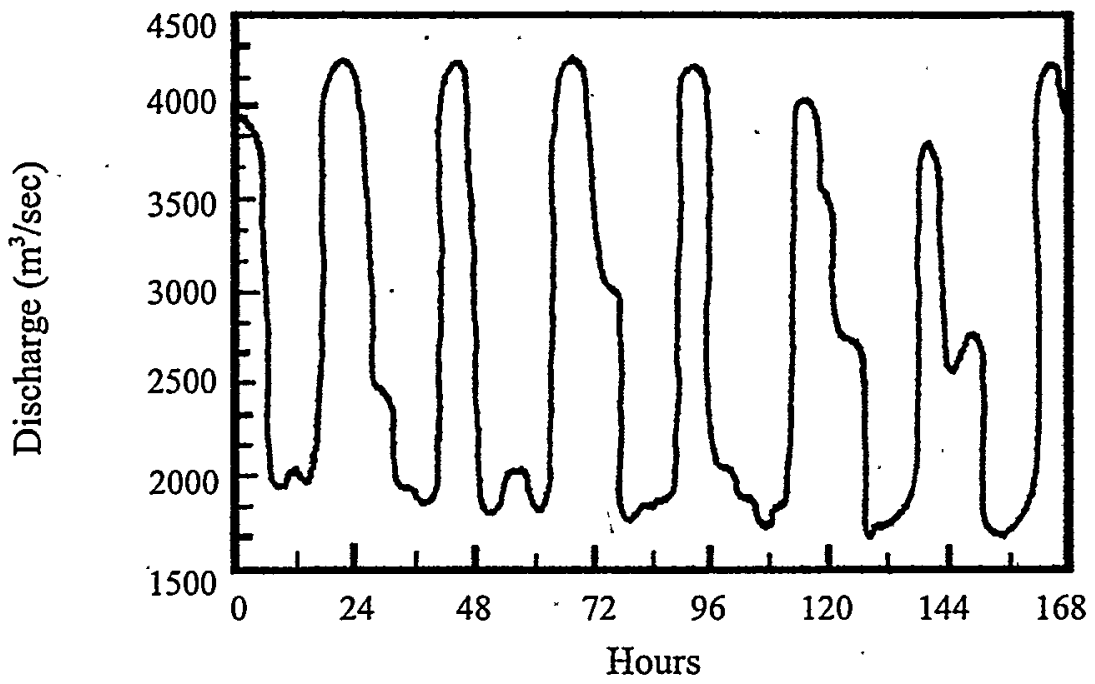

Figure 5. Example of Daily Flow Variation in the Hanford Reach During Fall Chinook Spawning (discharge from Priest Rapids Dam)

are approximately 18 islands that account for $64.2 \mathrm{~km}$ of island shoreline within the main channel of the Hanford Reach (USACE 1976 in USACE 1995). In conjunction with these islands are numerous side channels, backwater sloughs, and large gravel bars (Figure 6). These geomorphic features are very

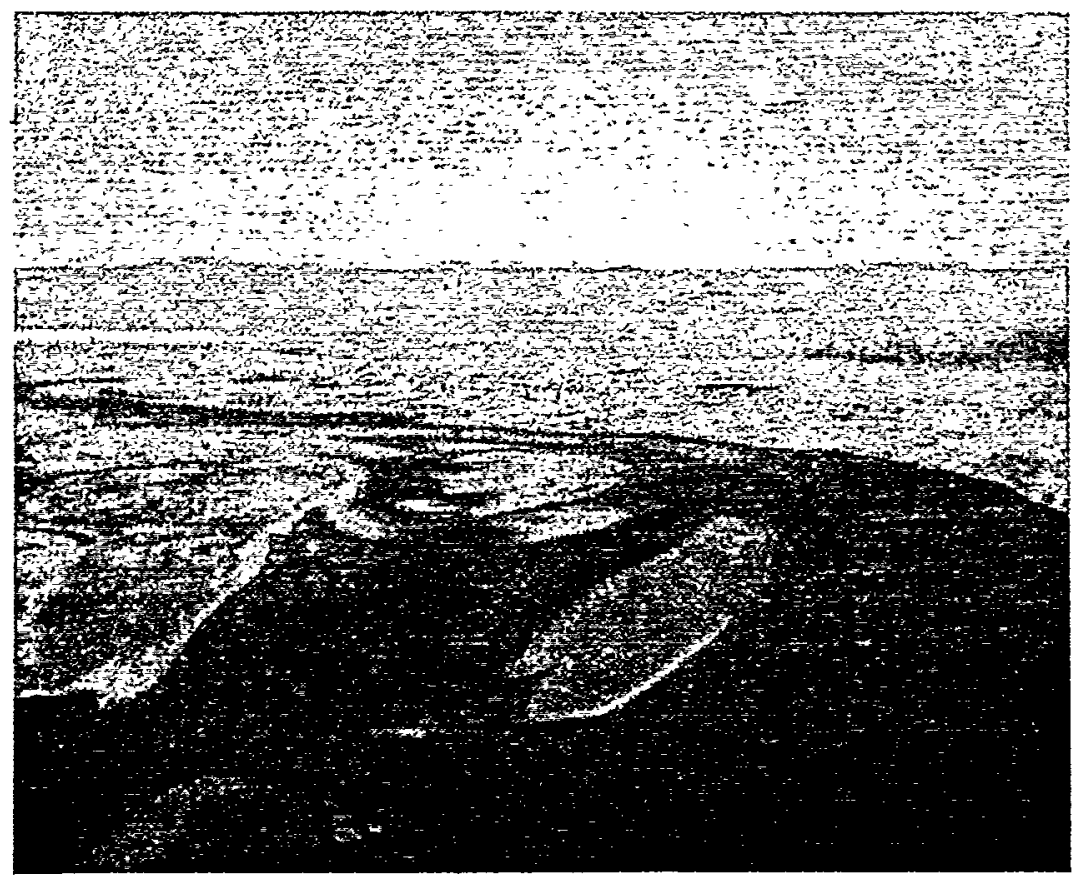

Figure 6. Aerial Photograph Exhibiting Some of the Channel Complexity (i.e., mid-channel islands, side channels, and backwater slough areas) Found in the Hanford Reach of the Columbia River 
important because they add complexity to the river system and provide habitat types that are used by fall chinook salmon during different life stages. For example, the extensive gravel bars associated with the islands are used by adult chinook for spawning grounds, and the network of side channels and backwater sloughs are rearing habitats used by juvenile chinook before they begin their migration to the ocean.

The Hanford Reach is extremely valuable because it provides an increasingly rare functioning aquatic ecosystem for fall chinook salmon. This system has remained resilient to degrading forces because of the buffering lands that have protected it. However, a change in land or water management may upset its current condition. If management changes occur, then effective non-intrusive monitoring is a must to measure their impacts on salmon.

\subsection{Study Site}

The study site covered 20 (rkm 587 to 607) of the Hanford Reach's $90 \mathrm{~km}$. Within the study site, nine areas of concentrated spawning, referred to as redd clusters, were identified and delineated. A redd cluster was defined as a site of concentrated spawning with more than 100 redds during 1994 and was separated from other redd clusters by a minimum distance of $50 \mathrm{~m}$. These redd clusters correspond with and are part of five defined spawning areas (Table 1) that have been identified and monitored annually since 1948 (Dauble and Watson 1997). The nine redd clusters and five areas included in the study site are located near several backwater sloughs and river island complexes that are known as the F-slough and Locke Island areas (Figure 7). Both the nine redd clusters and the five areas were used for analyses.

Table 1. Redd Clusters Found Within Designated Areas Defined by Dauble and Watson (1997)

\begin{tabular}{|c|c|}
\hline Dauble and Watson Areas & Redd Clusters \\
\hline Area 2 & 2A, 2B, and 2C \\
\hline Area 3 & 3A \\
\hline Area 4 & 4A and 4B \\
\hline Area 5 & 5A and 5B \\
\hline Area 7 & 7A \\
\hline
\end{tabular}




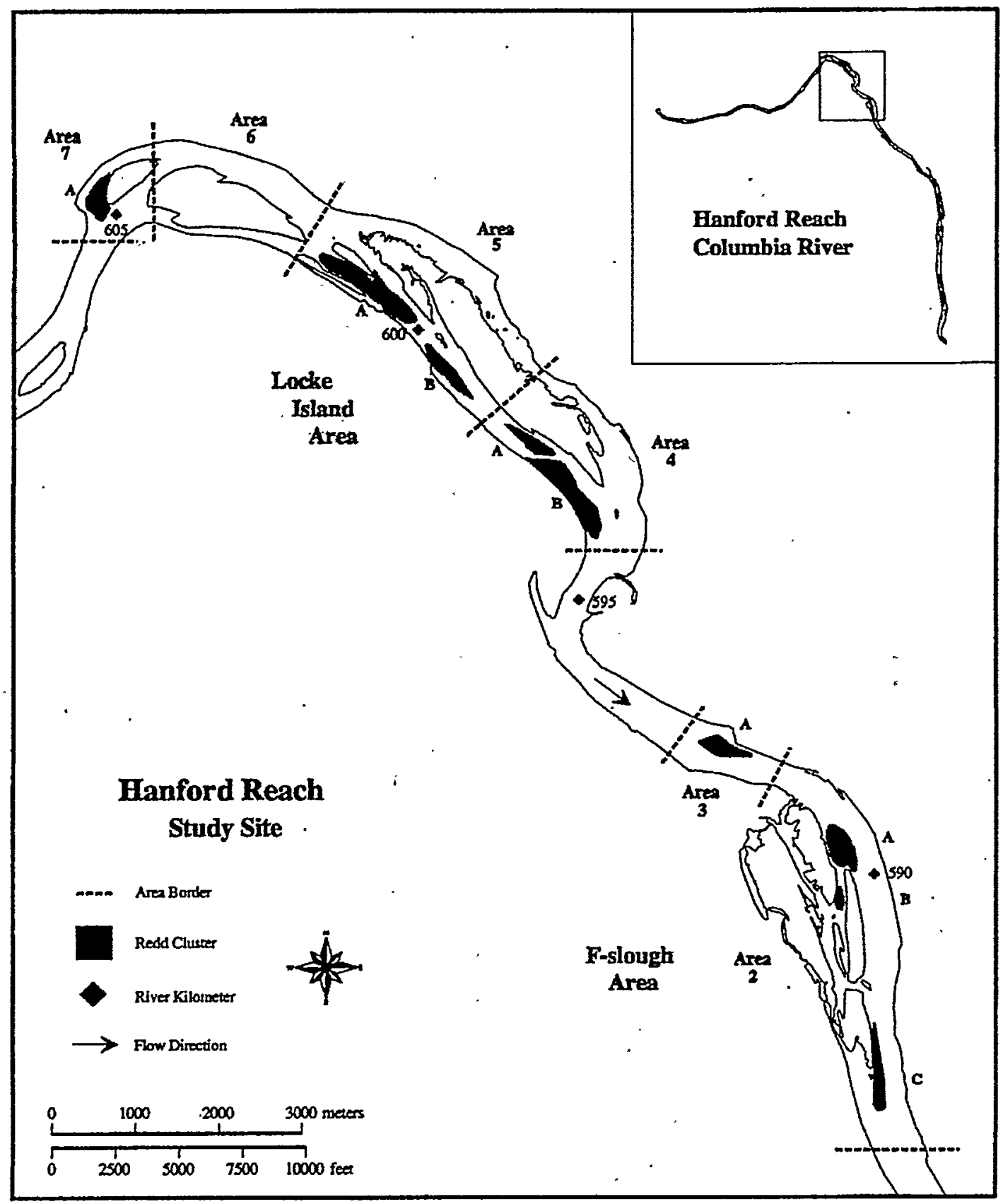

Figure 7. Study Site Within the Hanford Reach. Aerial photographs were taken here of fall chinook salmon spawning during 1991, 1994, and 1995. Spawning area designations follow Dauble and Watson (1990). Redd clusters are designated by letters and are defined in Table 1. 


\subsection{Methods}

This section describes the study's use of aerial photography and a Geographic Information System (GIS) to monitor fall chinook salmon spawning. Where applicable, this new approach will be compared with other techniques currently used. The section also briefly describes the process used by female salmon to construct their redds, which helps explain why redds are visible from the air. Specific methods are described for: 1) recording redds with aerial photography and digitizing images for analysis, 2) measuring redd characteristics, including redd counts, redd densities, and spatial characteristics and relationships, 3) comparing different monitoring techniques, specifically GIS analyses versus aerial survey redd counts, and 4) identifying possible key index sites and rating their relative potential of reflecting female escapement.

\subsection{Redd Construction}

It is essential to understand the process that salmon use to construct their nests because it explains why redds can be seen from the air. Fall chinook are brood hiders, or fish that build nests known as redds, where spawned eggs are buried. Before spawning occurs, the female chinook digs a shallow depression in the river's substrate by lying on her side and swimming or vigorously thrusting her caudal fin up and down (Figure 8). Performing this act causes cobble, gravel, and sand to be lifted from the

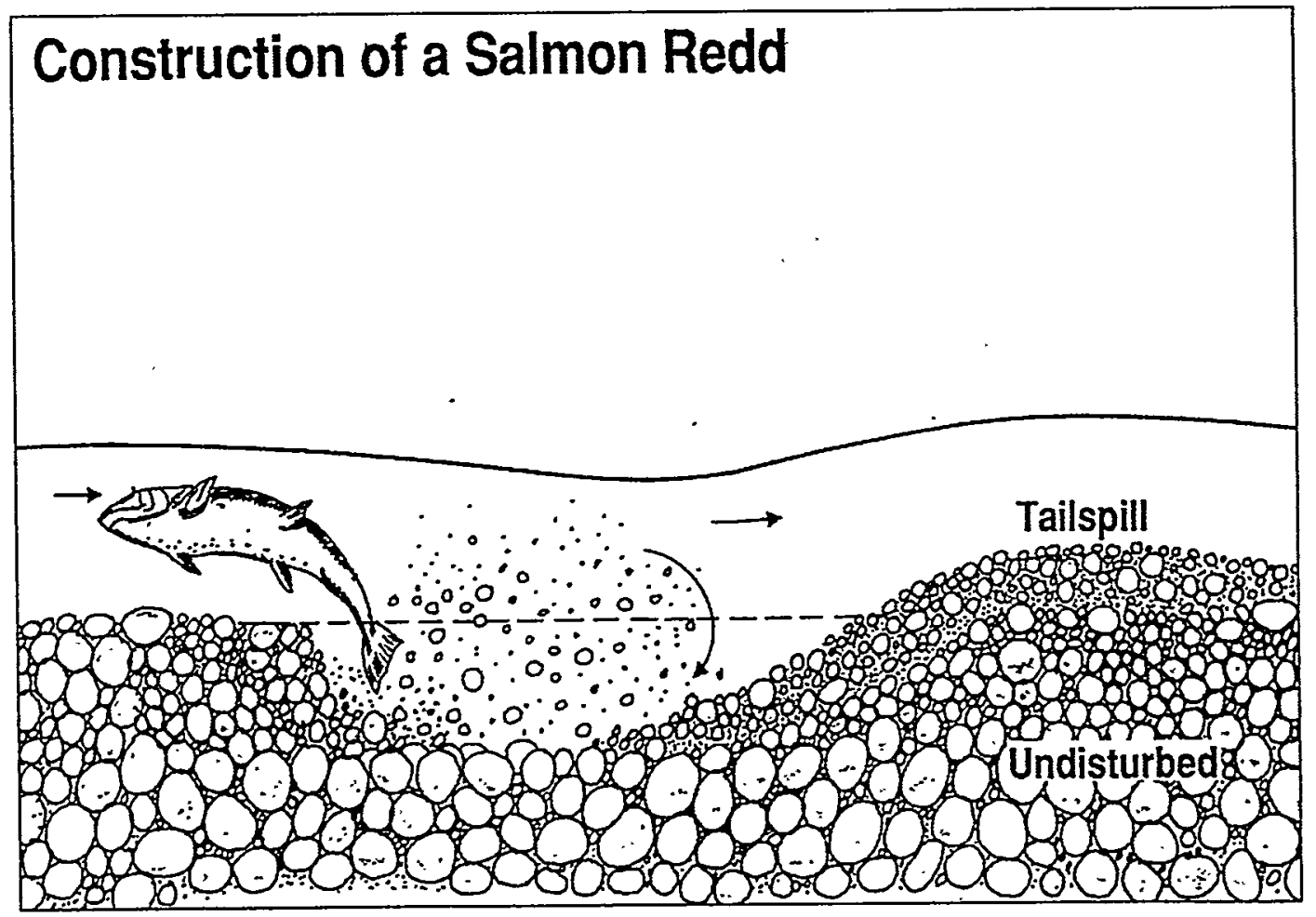

Figure 8. Line Drawing of a Female Salmon Disturbing the Substrate While Constructing a Redd 
riverbed and moved downstream by the river's current, leaving a depression upstream of a deposited mound or tailspill. After digging the depression, the female deposits a group or "pocket" of eggs, and one or more males deposits milt or sperm to fertilize the eggs. After depositing the eggs, the female will perform the same digging action just upstream to cover the fertilized eggs. Over the course of several days, the female will deposit two or more egg pockets within the same redd, moving upstream as she works. When the female is done spawning, she will guard the redd as long as she has energy to swim against the current and chase other salmon away from her nest. During this excavation process, the river substrate is moved and periphyton is partially removed from the spawning gravel leaving a disturbed or "cleaned" area. Consequently, these cleaned areas, or redds, are distinguishable from the surrounding matrix of undisturbed substrate making them visible from the air for more than 6 weeks (Dauble and Watson 1990).

\subsection{Photography and Image Analyses}

From 1948 to 1992, fall chinook spawning occurred in the Hanford Reach from October 26 to November 26, with the median peak date of spawning being November 11 (Dauble and Watson 1997). Photographs were taken of concentrated spawning sites in the Locke Island and F-slough areas (Areas 2 through 7 as defined by Dauble and Watson 1997). The photographs were taken once during peak spawning in 1991 (November 11) and over a 4-week period that included peak spawning for both 1994 (October 29, November 3, 9, and 12) and 1995 (October 29, November 6, 12, and 19). This time frame covered the expected interval when maximum redd densities would occur. The aerial photographs were taken from a fixed-wing airplane flying approximately $750 \mathrm{~m}$ above the water surface using a Pentax $6 \mathrm{x}$ $7(75 \mathrm{~mm})$ camera with Fuji 400 color film. Weather conditions were good during all photography flights (i.e., generally clear skies with low winds).

In 1991 and 1994, natural and manmade features of the landscape, the river shoreline, trees, and roads that had been digitized and mapped previously were used to provide geographic reference points to calculate the scale of the photographs taken during these years. In 1995, ground markers were placed throughout the study site, and geo-referenced coordinates for these markers were obtained using differentially corrected GPS readings taken at each marker. These ground markers were positioned approximately $90 \mathrm{~m}$ apart throughout the study site in two different patterns. The markers and landscape features were used to calculate the scale of the processed photographs and to verify the locations of redds when positioning the photographs for data input into the GIS. Because of altitude variations during the flights, the scales of the developed photographs ranged from 1:2,100 to 1:2,900. To correct problems associated with different scales, each photograph was digitized using a digital scanner (600 dpi) and adjusted to a common base scale of approximately 1:2,600.

River kilometers used in the analyses were mapped using aerial photographs and GIS cartographic techniques. River kilometer mapping was based on surveyed river miles that were marked on photographs produced by the U.S. Army Corps of Engineers. The locations of river miles were digitized into the GIS and used to calculate and place river kilometers in their proper location on a GIS data layer of the Columbia River.

Photography effectively distinguished and presented the contrast between the lighter colored redds and the darker surrounding undisturbed substrate (Figure 9). All redds visible on the aerial photographs 


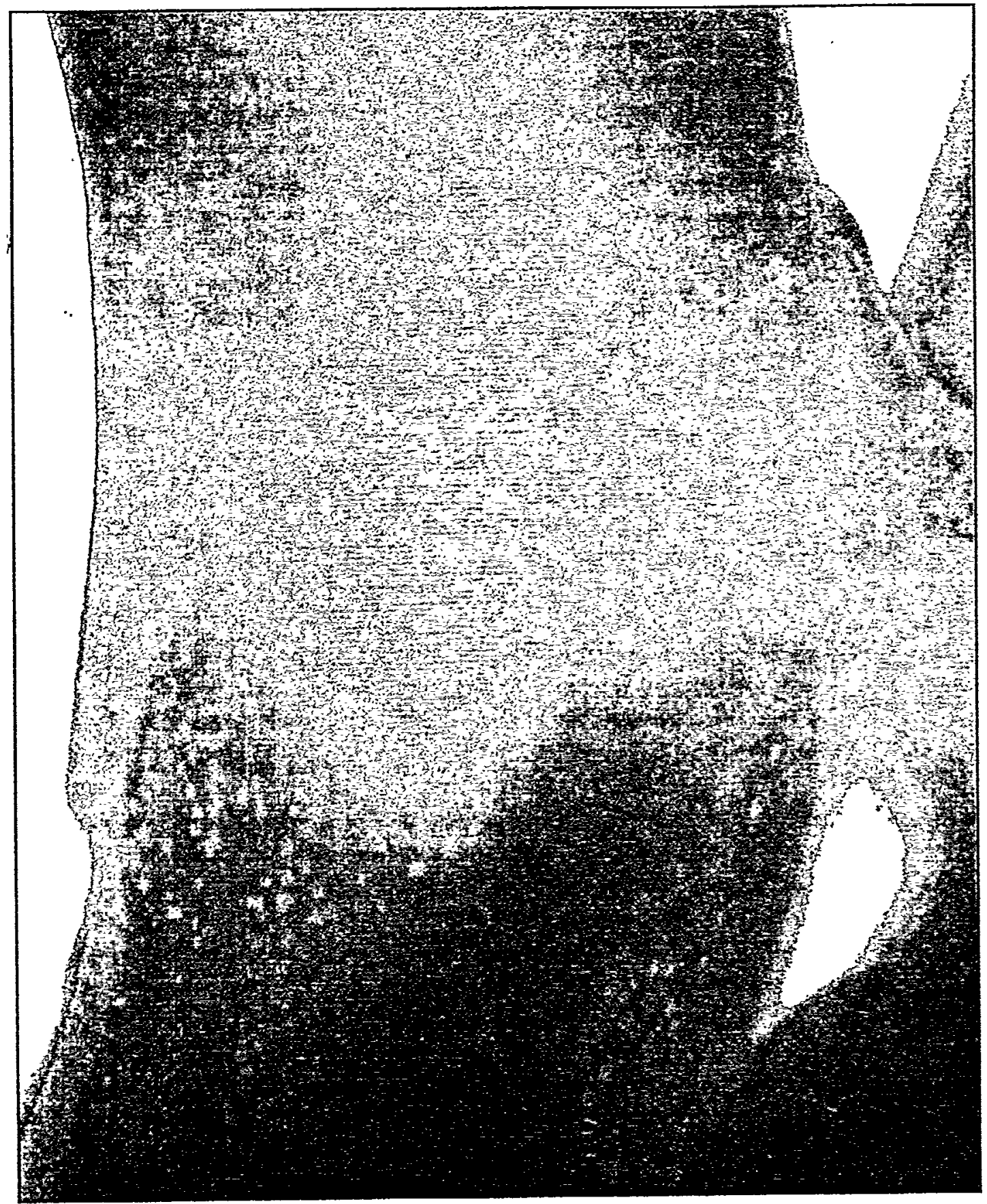

Figure 9. Scanned Color Aerial Photograph (converted to black and white) Showing Visible Redds in Cluster 4B (1994). Redds are light, and the surrounding matrix of unused substrate is dark. 
were digitized, mapped, counted, measured, and analyzed using a GIS (Arc/Info). Photographs taken in 1994 and 1995 were processed by digitizing redds from the first week and then adding locations of new redds for each subsequent week. A new redd was one that was found in a location where no redd was previously seen. Because only one set of photographs was taken and processed in 1991, counts for this year may not be directly comparable to 1994 and 1995. However, 1991 redd counts may help distinguish and identify trends when compared to 1994 and 1995 redd counts. In addition, 1991 GIS analysis counts used photographs taken one day after aerial surveys were conducted. Redd counts from 1991 using both of these techniques provided totals at one time for a direct comparison.

The maximum water depth at which redds can be detected during aerial redd surveys in the Hanford Reach was estimated by Dauble and Watson (1990) to be 3 to $4 \mathrm{~m}$. However, Chapman et al. (1986) reported that only shallow redds, in depths of $2.5 \mathrm{~m}$ or less, could be detected from the air during visual aerial surveys. Aerial photography appears to be slightly better at detecting redds compared to visual surveys; thus, it was assumed that $4 \mathrm{~m}$ (the maximum depth estimated by experienced surveyors) was the maximum depth of detection. Aerial photographs were taken during low flow days to maximize the number of redds that could be detected. On days that aerial photographs were taken, flows were estimated to range from 1,360 to $1,430 \mathrm{~m}^{3} / \mathrm{s}$ in 1994 , and nearly $1,570 \mathrm{~m}^{3} / \mathrm{s}$ in 1995 (Geist et al. 1997). This can be compared to a daily average discharge at Priest Rapids Dam that ranged from 1,200 to $3,800 \mathrm{~m}^{3} / \mathrm{s}$ during peak spawning from 1959 through 1985 (Dauble and Watson 1997). To establish the limits of aerial photography, one survey of depths greater than $4 \mathrm{~m}$ was made at Locke Island using an underwater video camera in late November 1995, but no additional redds were found. This suggests that water depth may not have a significant effect on the accuracy of the redd counts using the aerial photographs taken of this site because spawning was not observed in areas deeper than $4 \mathrm{~m}$.

\subsection{Redd Characteristics}

Redd characteristics measured and evaluated were the number and density of redds and spatial characteristics, including redd size, distance between nearest neighbor, and a distribution descriptor called an R-value.

\subsubsection{Redd Counts, Ratio to Female Escapement, and Density}

Redds were counted and enumerated for each distinct redd cluster on a weekly and yearly basis to derive weekly and total year-end redd counts. The relative proportion of total redd counts that each cluster contributed to the whole study area was plotted to determine if the proportion of redds per cluster was consistent during the 3 years that were surveyed.

To measure the limitations of using aerial photography to quantify redds, the number of detectable redds using aerial photography within the Hanford Reach was estimated for 1994 and 1995. This esti-

mate of detectable redds was compared to the number of female chinook available for spawning based 
on escapement estimates. Since the study site did not include the entire Hanford Reach, the number of redds that could have been detected for the whole reach was estimated. Redd counts from 1994 and 1995 were used in conjunction with the average proportion of redds that the study site had contributed to the total redd count of the Reach since 1964. Historically, from 1964 (the first year of adult escapement estimates) to 1995, the study site (Areas 2 through 7 as defined by Dauble and Watson 1997) contained approximately $58 \%$ (range 38 to $74 \%$ ) of the redds counted during aerial surveys in the Hanford Reach. The estimated total number of redds that were detectable using aerial photography within the Hanford Reach was calculated using Equation (1):

Total detectable redds $=$ Number of redds within the study site/ 0.58

Adult escapement, or the number of fall chinook salmon that migrate into the Hanford Reach to spawn, has been estimated using salmon passage counts from McNary, Ice Harbor, and Priest Rapids dams (Figure 10) since 1962 (the first year of passage counts from Ice Harbor Dam). Escapement was calculated by subtracting fall chinook counts recorded at Priest Rapids and Ice Harbor dams from counts recorded at McNary Dam (Grant County Public Utility District, Personal Communication 1996). Additional variables subtracted from the McNary Dam counts are: Yakima River estimated escapement (beginning in 1963), returns to Priest Rapids Hatchery (beginning in 1964), and the estimated Hanford Reach sport salmon catch (beginning in 1984).

The number of detectable redds was then compared to the estimated number of female chinook available to spawn in the Hanford Reach. The population of female chinook that was available to spawn was estimated by multiplying the total adult chinook escapement into the Hanford Reach by 0.545 , which represents the male-to-female sex ratio of 1:1.2 reported by Chapman et al. (1994). This allowed the ratio of detectable redds to female spawners within the Hanford Reach for both 1994 and 1995 to be estimated.

Redd density was calculated and reported based on two different measurements: habitat use density and segment density. Both measurements were based on the total number of redds per unit area (delineated redd cluster or river kilometer) that was mapped each year. Habitat use was measured with GIS analysis by delineating redds on the outer edge of each cluster. This measurement was dynamic and changed from year to year relative to both the size of the cluster and the number of redds. Habitat use density was calculated using Equation (2):

$$
\text { Habitat use density }=\text { redds per cluster/area of cluster }
$$

Measurements of segment density were based on defined river segments (i.e., river kilometers), which remained constant from year to year. Because river kilometers do not change from year to year, segment density may provide a more standard measurement of density among survey years until all suitable spawning habitat is identified and mapped. 


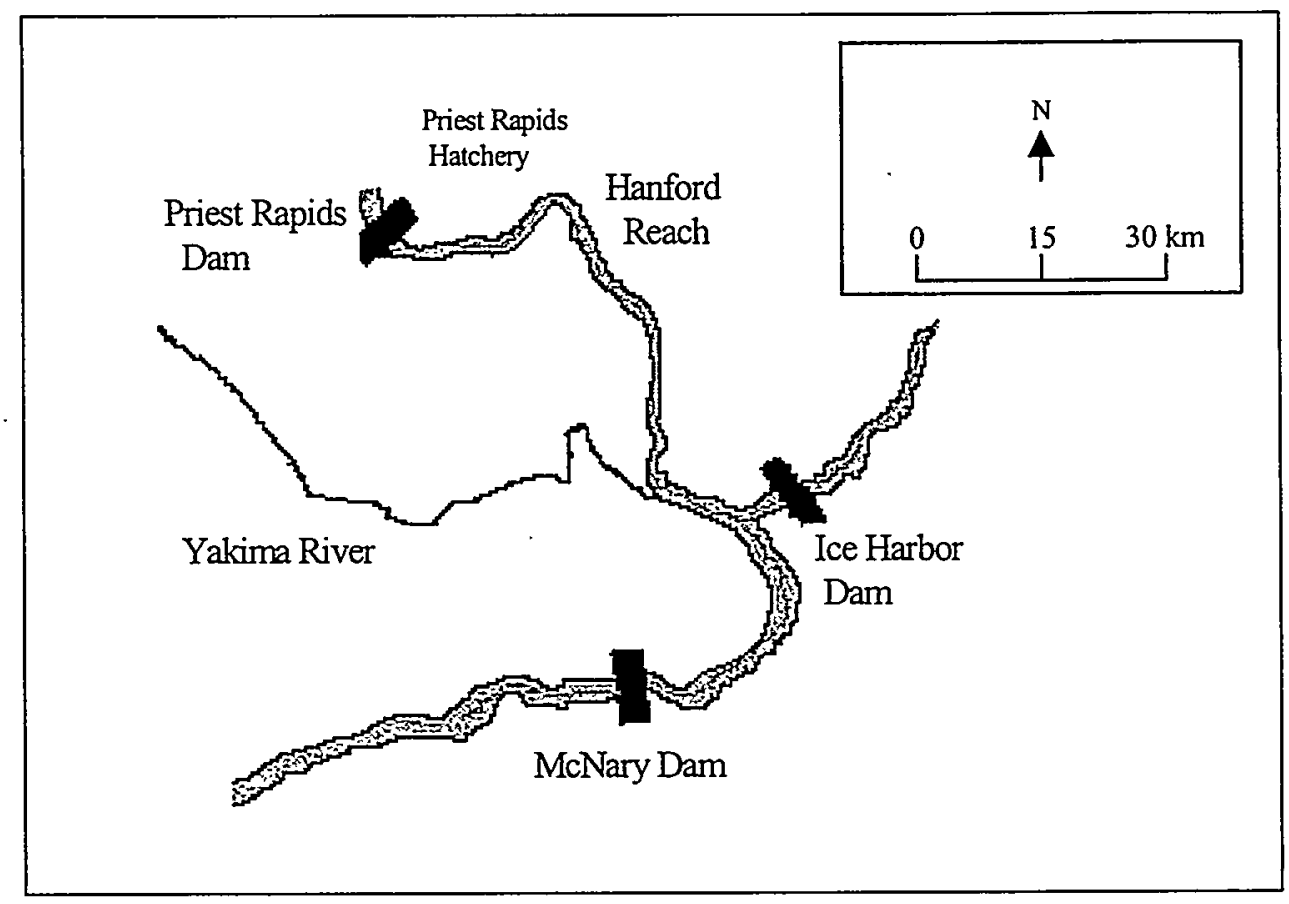

Figure 10. The Hanford Reach in Relation to McNary, Ice Harbor, and Priest Rapids Dams, the Priest Rapids Hatchery, and the Yakima River

\subsubsection{Redd Size and Area Disturbed Per Redd Cluster}

Redd size and the area of clean substrate within defined spawning clusters were measured in 1994 and 1995 to determine year-to-year and site-to-site variability. A sub-sample of redds from within each cluster was randomly selected, and the outer boundaries of these chosen redds were delineated and digitized. When redd locations were initially digitized into the GIS, a sequential number was assigned to each of them. A random number table was then used to select numbers, and redds with the corresponding numbers that had been assigned to them by the GIS were digitized. At least 20 redds were chosen from each week's photographs. When there were $<20$ new redds in a cluster for the week, all redds were digitized and measured.

The amount of disturbed substrate within each redd cluster was estimated to detect any changes from year to year or site to site in 1994 and 1995 . Yearly mean redd size per cluster was multiplied by the number of redds in each cluster to estimate the total area disturbed by redd construction. The percentage of disturbed substrate for each cluster was then calculated. 


\subsubsection{Redd Spatial Analysis}

Spatial distribution of redds within each redd cluster was analyzed by measuring nearest neighbor distance and inter-redd distance and by using a pattern descriptor called an R-value. Nearest neighbor distance (Figure 11) was determined using GIS analysis by measuring the center point of each redd (digitized point locations) to the center point of its nearest neighboring redd. Inter-redd distance (IRD) was calculated with Equation (3):

$$
\mathrm{IRD}=\mathrm{NND}-(\text { mean redd radius } \cdot 2)
$$

An $\mathrm{R}$-value is a simple spatial descriptor that can be used to describe the pattern of redds within a defined area as aggregate, random, or evenly distributed (Clark and Evans 1954; Neilson and Banford 1983). Spawning activity was used to define and delineate the areas used (redd clusters) for this evaluation. Data used to calculate an R-value included the mean distance to the nearest neighboring redd and the density of redds for each cluster. Equation (4) was used to calculate the R-values for each cluster:

$$
\mathrm{R}=\mathrm{rA} / \mathrm{rE}
$$

where $r_{A}$ is the mean nearest neighbor distance in the population or sample and $r_{E}$ is the mean nearest neighbor distance in an infinitely large spatial distribution of density $(\lambda)$ equal to that of the sample $\left(r_{E}-1 / 2 \sqrt{\lambda}\right.$ ) (Clark and Evans 1954; Forman and Godron 1986). The possible range of values for $R$ is 0.0 to 2.1491 , where 0.0 designates a completely aggregate distribution, 1.0 designates a random distribution, and 2.1491 designates a completely even distribution pattern. $\mathrm{R}$-values were calculated at the end of monitoring for each redd cluster and from week to week for each cluster. The week-to-week R-values for each redd cluster were graphed to show changes in redd distribution through the spawning season.

Redd size and distribution within redd clusters may be density dependent. Therefore, simple linear regression analyses were used to determine if there were any relationships between redd density and spatial redd characteristics. Habitat used density was plotted against the mean redd size, nearest neighbor distance, and R-value for each redd cluster in 1994 and 1995.

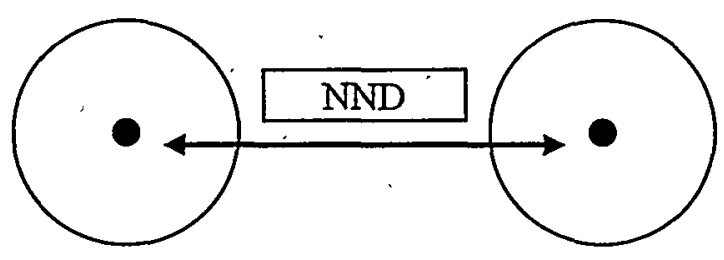

Figure 11. Nearest Neighbor Distance (NND) was Measured from the Center Point of a Redd to the Center Point of its Nearest Neighbor 


\subsection{Estimating Spawner Carrying Capacity}

Spatial relationships may provide a rough means to estimate the spawner carrying capacity of the Hanford Reach spawning grounds. A minimum carrying capacity was estimated using spatial measurements obtained from GIS analyses (mean redd size, mean inter-redd distance and total area of redd clusters) in conjunction with a conversion factor that estimates the proportion of habitat found within and outside the study site. The mean redd size and mean inter-redd distance were used to calculate the estimated area used per redd. The estimated area used per redd was then used with a set of equations to calculate an estimate of the number of redds needed to fully seed the study site, and then to estimate the minimum carrying capacity for the Hanford Reach. The equations used were:

$$
\begin{gathered}
\mathrm{EAU} / \mathrm{TCA}=\mathrm{RFS} \\
\mathrm{RC} / \mathrm{RFS}=\mathrm{CFE} \\
\mathrm{CFE} \cdot \mathrm{EE}=\mathrm{MCC}
\end{gathered}
$$

where $\mathrm{EAU}=$ Estimated area used per redd

$\mathrm{TCA}=$ Total cluster area in study site

RFS $=$ Redds to fully seed study site

$\mathrm{RC}=$ Redds counted in 1994

$\mathrm{CFE}=$ Conversion factor estimator

$\mathrm{EE}=$ Escapement estimate in 1994

$\mathrm{MCC}=$ Minimum carrying capacity.

Estimating minimum carrying capacity in this manner required two major assumptions: the 1) spatial relationships found in the study site were representative of those within the Hanford Reach, and 2) number of detectable redds was proportional to escapement numbers into the Hanford Reach.

\subsection{GIS Analyses Versus Aerial Surveys and Dam Counts .}

Redd counts from Areas 2 through 7 (Dauble and Watson 1990) were compared to redd counts enumerated using aerial photography with GIS analyses. The two monitoring techniques determined the final count per area differently. For example, photographs were processed by digitizing redds from the first week and then adding "new" redds for each subsequent week, with total redds per area being the cumulative total of all 4 weeks. In contrast, aerial surveys did not rely on individual redds seen during surveys in previous weeks. Rather, the highest redd count of each area over the course of all surveys for the year was used to provide a total, or "peak," redd count for each area.

Four comparisons were made between these two monitoring techniques. The comparisons were to determine if these methods gave similar results or if one was more informative and/or accurate. Criteria used to assess relative accuracy included the following questions: 1) did the methods result in the same or different total redds counted per area at the end of the monitoring season, 2) did the techniques result in the same or different redd counts when aerial photographs were taken and aerial survey were conducted 
one day apart from each other in 1991, 3) did the techniques result in the same or different redd counts over time during the 1994 and 1995 spawning season, and 4) if redd counts were different, which technique more accurately reflected escapement estimates?

In the first comparison, the relative proportion of the yearly total redds counted using both techniques was plotted for Areas 2 through 7 for 1991, 1994, and 1995. In the second comparison, redd counts from 1991 at near peak spawning were used. During 1991, photographs were taken on November 11, and aerial survey counts were taken on November 10 , only 1 day apart. Next, the total redd counts from week to week were plotted to determine if there were any temporal similarities or differences in redd counts between the two techniques. This comparison was then performed for each of the six areas to determine the amount of variability between redd counts from area to area for the two methods during 1994 and 1995.

The final comparison used to detect differences between the total redd count determined by the two techniques was based on estimates of female fall salmon chinook escapement. Total redd counts of Areas 2 through 7 obtained from aerial surveys and from individual redd clusters using GIS analysis were compared to yearly estimated female escapement for 1991, 1994, and 1995.

A major consideration for these evaluations was that there were only 2 years of data available for most comparisons: 1994 and 1995. The GIS counts from 1991 were not comparable to counts taken in 1994 and 1995 because only one set of photographs was taken in 1991 versus four sets in both 1994 and 1995. However, redd counts for 1991 were the only valid data set that could be use to compare redd counts from both techniques that were not influenced by the "additive" method (GIS analyses) or the "peak" method (aerial surveys) of counting redds. With all comparisons, it was assumed that the results of the redd counts using these two methods were typical at these escapement levels. Consequently, they may not be valid for years with higher or lower escapement levels.

\subsection{Identifying Key Index Sites}

Defined redd clusters (study spatial units) and areas (Dauble and Watson 1997) were examined to determine which redd clusters and areas best represented the population of spawning adults in 1994 and 1995, thereby identifying potential key index sites. For this evaluation, estimated female escapement was used as the reference point to compare and rate a spawning site's value as an index site. The number of redds counted in each site as a percentage of estimated female escapement and the coefficient of variation (CV) between the 2 years for each area and redd cluster were calculated. A low CV signifies less variability between the 2 years, identifying spatial units that are more consistent at reflecting escapement estimates. The CV for each unit was compared and used to place a relative ranking for all areas and clusters. The sites with the lowest CV were considered the best indicators of estimated escapement. 


\subsection{Results}

A total of 15,744 fall chinook salmon redds were digitized into a GIS based on aerial photographs taken during the 1991, 1994, and 1995 spawning seasons. Of this total, 11,732 (75\%) were located within the nine defined redd clusters (Figure 7). About $13 \%$ of the redds located within these redd clusters were randomly selected, digitized, and measured to estimate redd size. Results that evaluated the effectiveness of using aerial photography in conjunction with GIS for monitoring purposes were organized into four sections: 1) analyzing redd characteristics, including the number of redds counted, redd density, redd size, area disturbed within each cluster, and spatial analyses; 2) estimating carrying capacity using spatial measurements associated with redds; 3 ) monitoring spawning activity using GIS analyses compared to aerial surveys; and 4). identifying key index sites and their relative potential for accurately reflecting female escapement.

\subsection{Redd Characteristics}

\subsubsection{Redd Counts, Ratio to Female Escapement, and Density}

The total redd count for the study site and redd count per cluster exhibited considerable variation over the 3 years of study using aerial photographs with GIS analyses. In 1991, the total number of redds counted in the nine redd clusters was 1,662 (aerial photographs were taken on only 1 day of the spawning season). In 1994 and 1995, total redd count was 6,314 and 3,756, respectively (aerial photographs were taken on 4 different days over 4 weeks during the spawning season). When examining individual redd clusters among years, it was obvious that there was a large variation in the number of redds from year to year (Table 2). For example, the total redds counted in cluster 4B ranged from 313 in 1991 to 1,233 in

Table 2. Redd Counts Based on Aerial Photographs and GIS Analyses for Defined Redd Clusters in the Hanford Reach for 1991, 1994, and 1995

\begin{tabular}{|c|c|c|c|c|c|c|}
\hline \multirow[b]{2}{*}{ Area } & \multirow[b]{2}{*}{ Cluster } & \multicolumn{5}{|c|}{ Redds Per Cluster } \\
\hline & & 1991 & 1994. & 1995 & Mean & $\begin{array}{c}\text { Standard } \\
\text { Deviation }\end{array}$ \\
\hline \multirow[t]{3}{*}{2} & A & 299 & 850 & 544 & 564 & 276 \\
\hline & B & 46 & 152 & 87 & 95 & 53 \\
\hline & $\mathrm{C}$ & 40 & 474 & 149 & 221 & 226 \\
\hline 3 & $\mathrm{~A}$ & 128 & 400 & 161 & 230 & 148 \\
\hline \multirow[t]{2}{*}{4} & A & 86 & 375 & 204 & 222 & 145 \\
\hline & $\mathrm{B}$ & 313 & 1,233 & 740 & 762 & 460 \\
\hline \multirow[t]{2}{*}{5} & $\mathrm{~A}$ & 403 & 1,565 & 1,039 & 1,002 & 582 \\
\hline & $\mathrm{B}$ & 48 & 546 & 249 & 281 & 251 \\
\hline 7 & $\bar{A}$ & 299 & 719 & 583 & 534 & 214 \\
\hline \multicolumn{2}{|c|}{ Total } & 1,662 & 6,314 & 3,756 & 3,911 & 2,330 \\
\hline
\end{tabular}


1994, and counts in cluster 5A ranged from 403 in 1991 to 1,565 in 1994. Despite the large variation in the number of redds counted from year to year, the proportion of redds within each cluster was relatively constant (Figure 12). Cluster 5A accounted for the largest proportion of redds counted per year (range 24 to $28 \%$ ), while cluster $2 \mathrm{~B}$ accounted for the smallest proportion per year (range 2 to $3 \%$ ). It should be noted that redd clusters had a wide range in size (e.g., the area of cluster $2 \mathrm{~A}$ was nearly 10 times larger than cluster 5B for both 1994 and 1995).

The estimated number of detectable redds was 14,228 in 1994 and 8,755 in 1995 . Total escapement of adult fall chinook salmon into the Hanford Reach was 48,857 in 1994 and 32,288 in 1995. In 1994, the estimated female escapement was 26,627, and in 1995 it was 17,597. The estimated number of detectable redds accounted for 53 and $50 \%$ of the estimated female escapement within the Hanford Reach for 1994 and 1995, respectively. These values translate into a detectable redd to female ratio of 1:1.9 in 1994, and 1:2.0 in 1995, assuming one redd was constructed by each female chinook salmon (detectable redd to adult chinook ratios were 1:3.4 in 1994, and 1:3.7 in 1995).

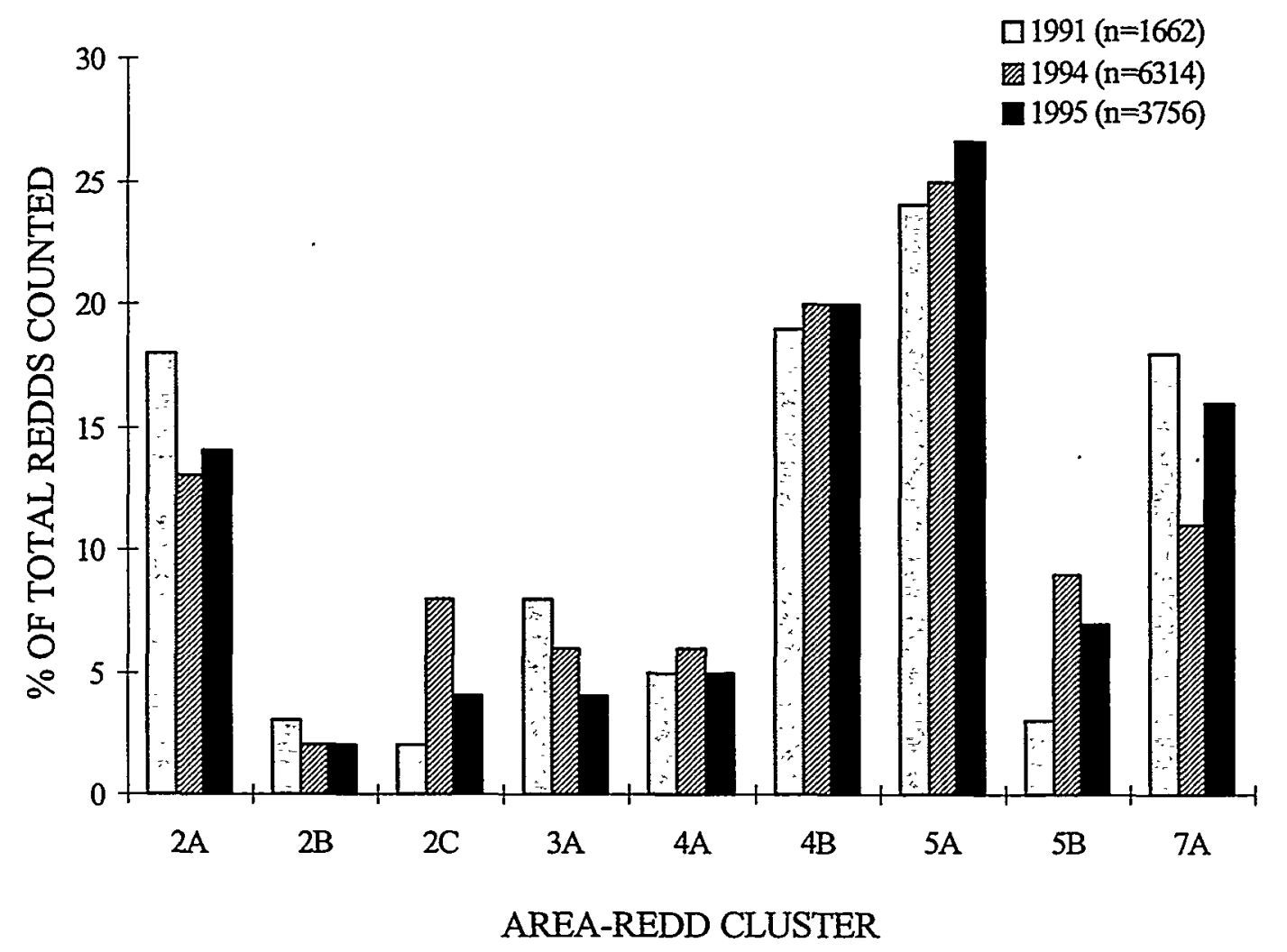

Figure 12. Relative Proportion of Redds Per Defined Redd Cluster in the Hanford Reach for 1991, 1994, and 1995 
Habitat use density, or the density of redds found within each redd cluster, was higher in 1994 than 1995 with a mean of 73 redds/hectare in 1994, compared to 54 redds per hectare in 1995 (Table 3). The difference between the 2 years was statistically significant $(t=2.11, P<0.05)$. Each individual cluster exhibited a higher density in 1994 than in 1995, except cluster 7A, which had the highest density for both years ( 84 redds per hectare). The higher densities in 1994 corresponded with higher redd counts and a higher escapement estimate in 1994 compared to 1995. There was also less variation in the range of densities per cluster in 1994 (range 84 to 56 redds per hectare) compared to 1995 (range 84 to 32 redds per hectare). Segment density, or redds per kilometer, changed dramatically between 1994 and 1995 . For example, density in river kilometer 600 was 286, 1,215, and 806 redds per kilometer for 1991, 1994, and 1995 , respectively. These relatively large variances in redds per kilometer between the years were seen throughout the study site. However, the relative proportion of redds per kilometer to total redds counted was similar for most river kilometers among these years (Figure 13).

Table 3. Density of Redds Based on Aerial Photographs and GIS Analyses for Each Redd Cluster in the Hanford Reach for 1994 and 1995

\begin{tabular}{|c|c|c|c|c|c|c|c|}
\hline \hline Area & Cluster & $\begin{array}{c}1994 \text { \# of } \\
\text { Redds }\end{array}$ & Area (ha) & $\begin{array}{c}\text { Density } \\
\text { Redds/ha }\end{array}$ & $\begin{array}{c}1995 \text { \# of } \\
\text { Redds }\end{array}$ & Area (ha) & $\begin{array}{c}\text { Density } \\
\text { Redds/ha }\end{array}$ \\
\hline \hline 2 & A & 850 & 11.09 & 77 & 544 & 8.68 & 63 \\
\hline & B & 152 & 1.92 & 79 & 87 & 1.52 & 57 \\
\hline & C & 474 & 8.54 & 56 & 149 & 4.73 & 32 \\
\hline 3 & A & 400 & 6.40 & 63 & 161 & 3.83 & 42 \\
\hline 4 & A & 375 & 4.84 & 78 & 204 & 3.30 & 62 \\
\hline & B & 1,233 & 18.55 & 66 & 740 & 15.59 & 47 \\
\hline 5 & A & 1,565 & 19.94 & 78 & 1,039 & 18.61 & 56 \\
\hline & B & 546 & 7.42 & 73 & 249 & 5.41 & 46 \\
\hline 7 & A & 719 & 8.57 & 84 & 583 & 6.92 & 84 \\
\hline \multicolumn{2}{|l}{ Total } & 6,314 & 87.27 & 73 & 3,756 & 68.82 & 54 \\
\hline
\end{tabular}

\subsubsection{Redd Size and Area Disturbed Per Redd Cluster}

In 1994, the minimum redd size measured was $7.5 \mathrm{~m}^{2}$, and the maximum redd size measured was $40.5 \mathrm{~m}^{2}$ with a mean of $21.2 \mathrm{~m}^{2}$. In 1995 , the minimum size was $9.1 \mathrm{~m}^{2}$, and the maximum size was $61.8 \mathrm{~m}^{2}$ with a mean redd size of $23.4 \mathrm{~m}^{2}$ (Table 4). All three measurements increased in 1995 compared to those in 1994 when both density and escapement were considerably higher. There was a significant difference between the two years in mean redd size $(t=-2.34, P<0.05)$ and maximum redd size $(t=-$ $2.79, \mathrm{P}=0.01)$ but not in minimum redd size $(\mathrm{t}=-1.03, \mathrm{P}=0.32)$. The mean redd size for each cluster in 1994 ranged from 18.7 to $23.3 \mathrm{~m}^{2}$, while in 1995 , the mean redd size ranged from 21.3 to $27.5 \mathrm{~m}^{2}$. The coefficient of variation for the population means calculated for all redd clusters ranged from 23 to $30 \%$ in 1994 , compared to a range of 16 to $38 \%$ in 1995, which indicated that redd size was less variable in 1994 than it was in 1995. 


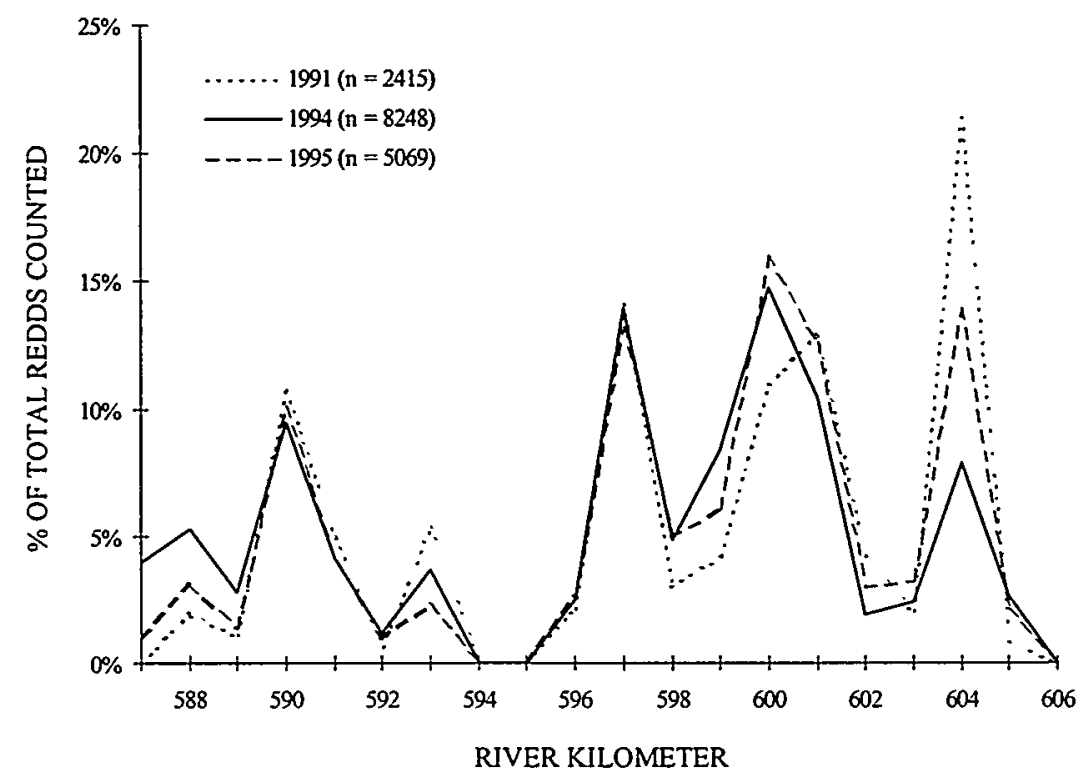

Figure 13. Relative Proportion of Redds Counted Per River Kilometer in the Hanford Reach for 1991, 1994, and 1995

Table 4. Redd Size Measured Using Aerial Photography and GIS Analyses for Each Redd Cluster in the Hanford Reach During 1994 (a) and 1995 (b) .

\begin{tabular}{|c|c|c|c|c|c|c|}
\hline \multicolumn{7}{|c|}{ a. 1994 Redd Size (squared meter) } \\
\hline Area & Cluster & Minimum & Maximum & Mean & Standard Deviation & $\mathrm{CI}$ \\
\hline \multirow[t]{3}{*}{2} & A & 10.6 & 41.0 & 22.9 & 6.0 & 1.26 \\
\hline & B & 14.2 & 34.9 & 22.9 & 5.2 & 1.15 \\
\hline & $\mathrm{C}$ & 8.3 & 40.6 & 22.8 & 6.9 & 1.48 \\
\hline 3 & $\mathrm{~A}$ & 11.3 & 37.2 & 23.3 & 6.0 & 1.28 \\
\hline \multirow[t]{2}{*}{4} & A & 7.5 & 31.5 & 18.9 & 4.9 & 1.19 \\
\hline & $\mathrm{B}$ & 10.3 & 37.9 & 20.3 & 5.7 & 1.00 \\
\hline \multirow[t]{2}{*}{5} & $\mathrm{~A}$ & 9.0 & 36.7 & 19.9 & 5.8 & 1.22 \\
\hline & $\mathrm{B}$ & 8.8 & 36.2 & 21.8 & 5.9 & 1.20 \\
\hline 7 & $\mathrm{~A}$ & 10.2 & 32.2 & 18.7 & 5.0 & 1.01 \\
\hline \multicolumn{7}{|c|}{ b. 1995 Redd Size (squared meter) } \\
\hline \multirow[t]{3}{*}{2} & $\mathrm{~A}$ & 10.9 & 36.8 & 21.3 & 5.4 & 1.01 \\
\hline & B & 10.0 & 39.5 & 21.4 & 6.4 & 1.72 \\
\hline & $\mathrm{C}$ & 15.3 & 43.5 & 27.5 & 5.5 & 1.29 \\
\hline 3 & $\bar{A}$ & 13.2 & 35.5 & 23.6 & 3.9 & 1.05 \\
\hline \multirow[t]{2}{*}{4} & A & 10.0 & 42.9 & 23.4 & 8.9 & 1.99 \\
\hline & B & 9.2 & 61.9 & 25.3 & 9.2 & 1.85 \\
\hline \multirow[t]{2}{*}{5} & $\mathrm{~A}$ & 11.9 & 47.4 & 22.8 & 7.5 & 1.49 \\
\hline & $\mathrm{B}$ & 9.4 & 44.1 & 24.4 & 8.6 & 1.72 \\
\hline 7 & $\mathrm{~A}$ & 9.2 & 47.4 & 21.3 & 7.3 & 1.59 \\
\hline
\end{tabular}


The percentage of area disturbed by spawning within each redd cluster (Figure 14) was higher in 1994 than in 1995 for all clusters except 7A (15.7\% in 1994 versus $17.9 \%$ in 1995). The mean percentage of area covered within all clusters during 1994 was $15.4 \%$ compared to $12.6 \%$ in 1995 . The area of each cluster was also larger in 1994 than in 1995 (Figure 15). For example, the largest redd cluster for both years was $5 \mathrm{~A}$, which had an area of $199,430 \mathrm{~m}^{2}(15.6 \%$ of the area disturbed $)$ in 1994 . This cluster was nearly $7 \%$ smaller in 1995 (12.7\% of the area disturbed). All redd clusters had less than $20 \%$ of their areas disturbed for both years.

\subsubsection{Redd Spatial Analyses}

The mean nearest neighbor distances for redd clusters were less in 1994 than in 1995 (Table 5). This difference was statistically significant $(\mathrm{t}=-3.46, \mathrm{P}<0.01)$. The mean distance between nearest neighbors for all clusters in 1994 was $8.1 \mathrm{~m}$ (range 7.8 to $8.8 \mathrm{~m}$ ), while in 1995 it was $9.7 \mathrm{~m}$ (range 7.9 to $12.1 \mathrm{~m}$ ). The R-values, or spatial descriptors, were relatively constant for both years at the end of the monitoring period. The R-values for both 1994 and 1995 ranged from 1.30 to 1.46 with a mean of 1.39 and a standard deviation of 0.04 . These values indicated that the spatial pattern of redds within each redd cluster tended toward a uniform, or even, distribution not an aggregate or random distribution. An analysis of $R$ values from the beginning to the end of monitoring showed that nearly all redd clusters advanced from an aggregate or random distribution of redds to an even distribution (Figure 16). This change occurred early in the spawning season at low densities, but the $\mathrm{R}$-values continued to increase until the end of monitoring.

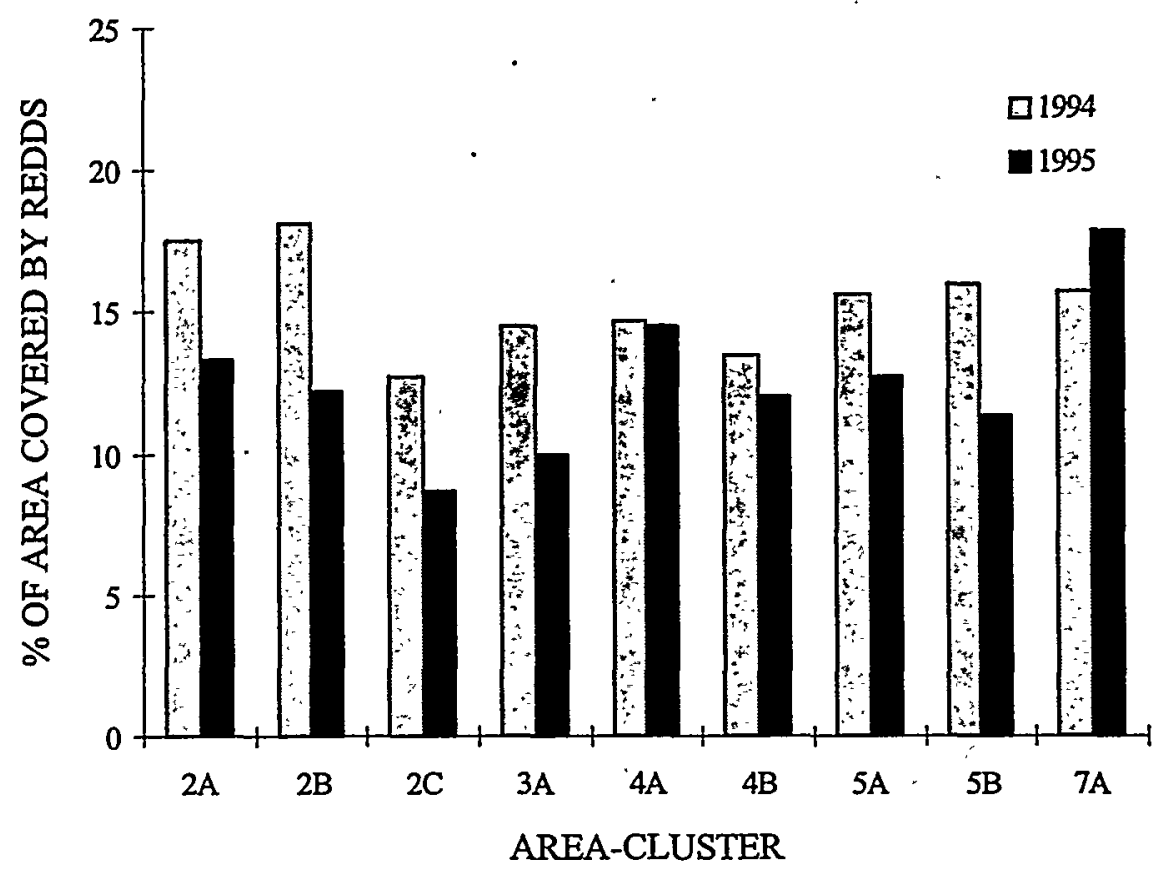

Figure 14. Proportion of the Total Area Disturbed in Each Redd Cluster in the Hanford Reach During 1994 and 1995 


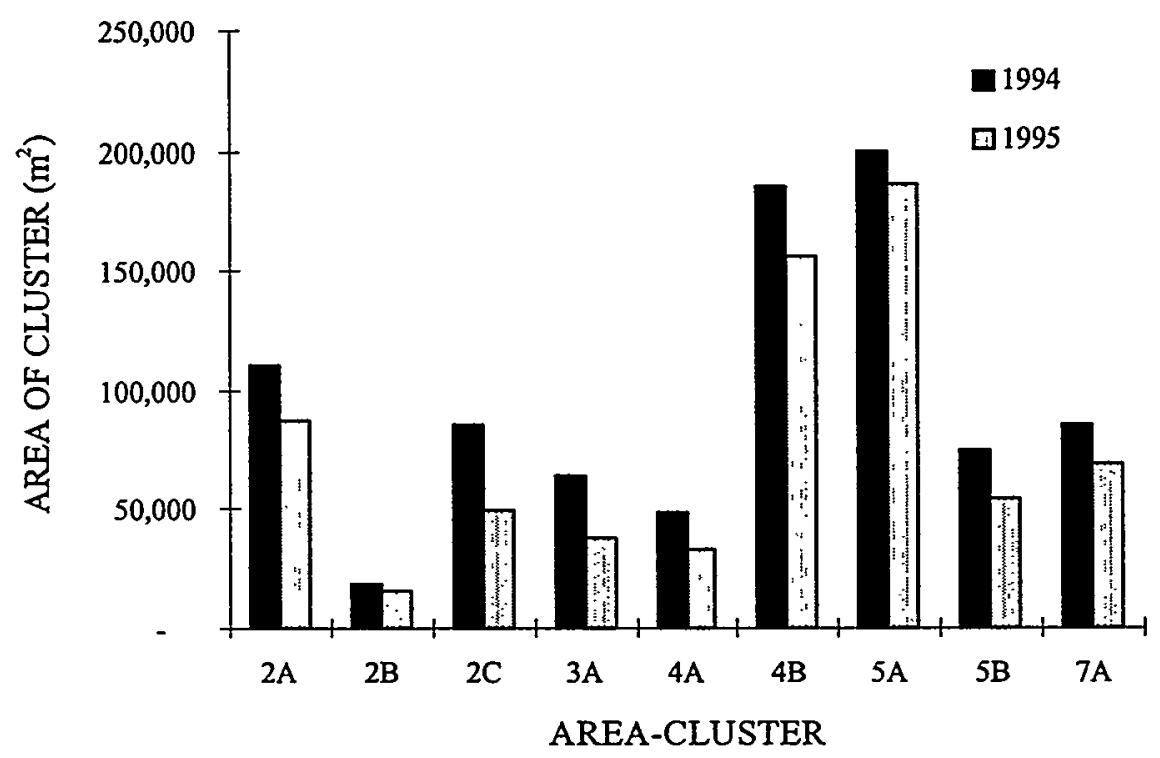

Figure 15. Total Area Disturbed in Each Redd Cluster in the Hanford Reach During 1994 and 1995

Table 5. Mean Nearest Neighbor Distance Measured with GIS Analyses for Each Redd Cluster in the Hanford Reach During 1994 and 1995

\begin{tabular}{|c|c|c|c||}
\hline Area & Cluster & $\begin{array}{c}\text { 1994 Mean Nearest } \\
\text { Neighbor (m) }\end{array}$ & $\begin{array}{c}\text { 1995 Mean Nearest } \\
\text { Neighbor (m) }\end{array}$ \\
\hline \hline 2 & A & 8.0 & 8.6 \\
\hline & B & 7.9 & 9.5 \\
\hline & C & 8.7 & 12.1 \\
\hline 3 & A & 8.8 & 11.1 \\
\hline 4 & A & 7.8 & 8.6 \\
\hline & B & 8.1 & 9.8 \\
\hline 5 & A & 7.9 & 9.4 \\
\hline & B & 8.1 & 10.5 \\
\hline 7 & A & 7.9 & 7.9 \\
\hline \multicolumn{2}{|r}{} & 8.1 & 9.7 \\
\hline
\end{tabular}


a.

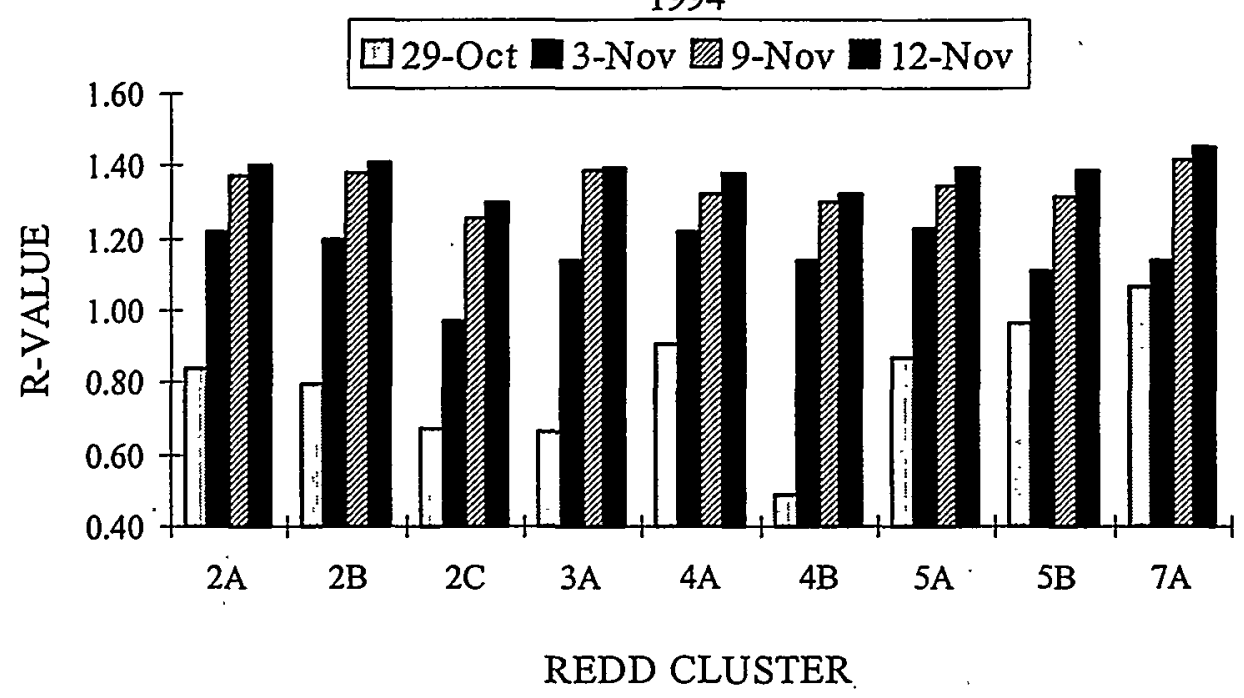

b.

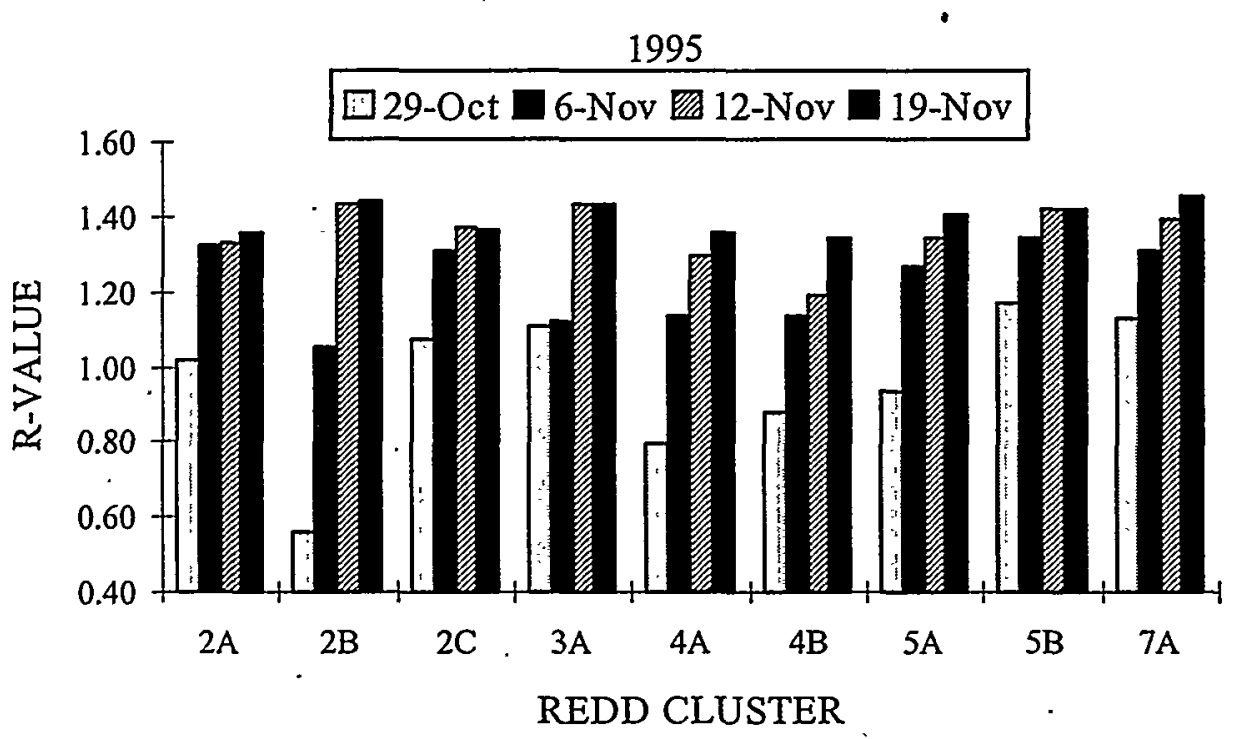

Figure 16. R-Values Calculated Using GIS Analyses for Each Redd Cluster in the Hanford Reach During 1994 (a) and 1995 (b)

Simple linear regressions of density (dependent variable) to redd size and other spatial characteristics (independent variables) were performed to determine if there were any relationships between these variables in 1994 and 1995. There was a statistically significant negative correlation between redd density and average redd size $(r=0.79, p<0.0001, d f=17$; Figure 17) for all redd clusters. There was also a statistically significant negative correlation between redd density and mean distance between nearest neighbors $(\mathrm{r}=0.83, \mathrm{p}<0.0001, \mathrm{df}=17$; Figure 18) for all redd clusters. There may have been a positive relationship between redd densities and R-values, but available data from 1994 and 1995 did not strongly support this $(r=0.29, p<0.0001, d f=17$; Figure 19). 


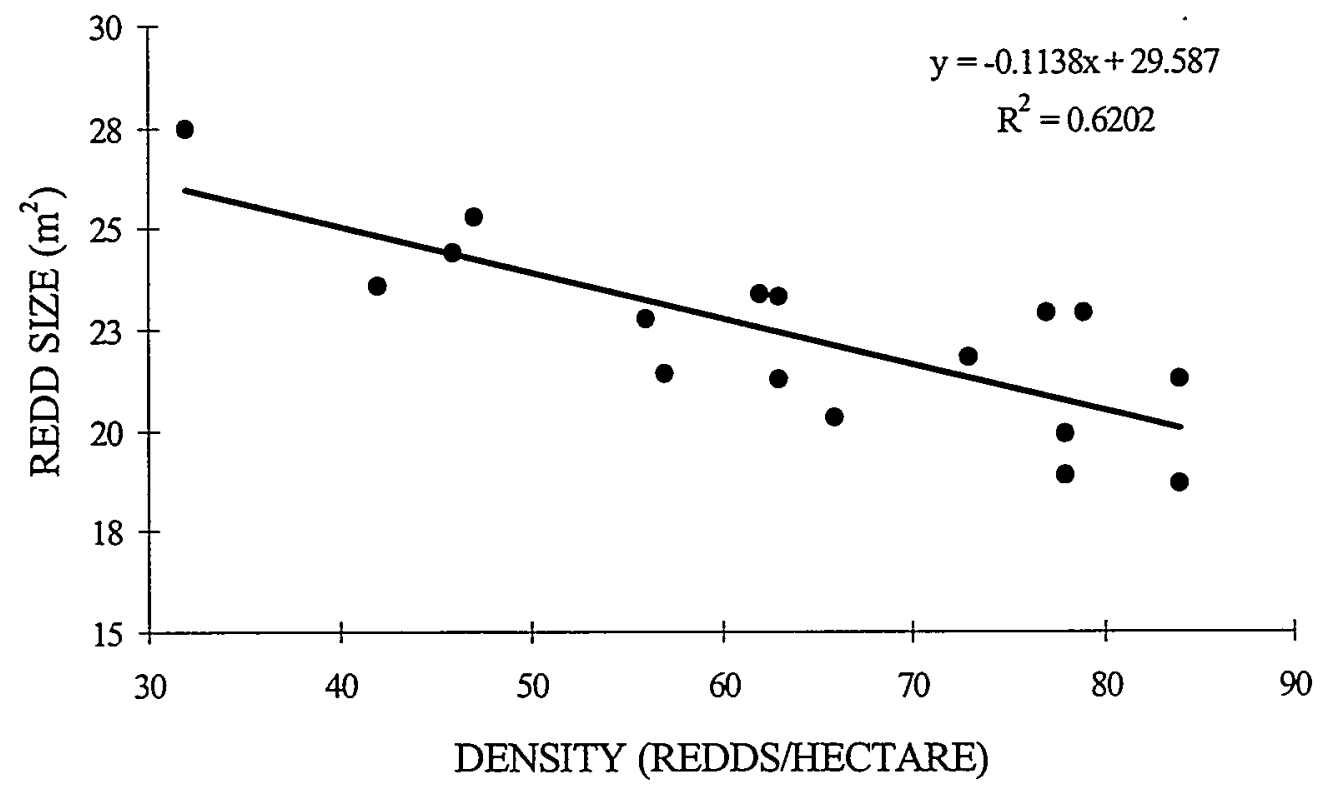

Figure 17. The Relationship Between Redd Density and Redd Size Within the Study Site During 1994 and 1995

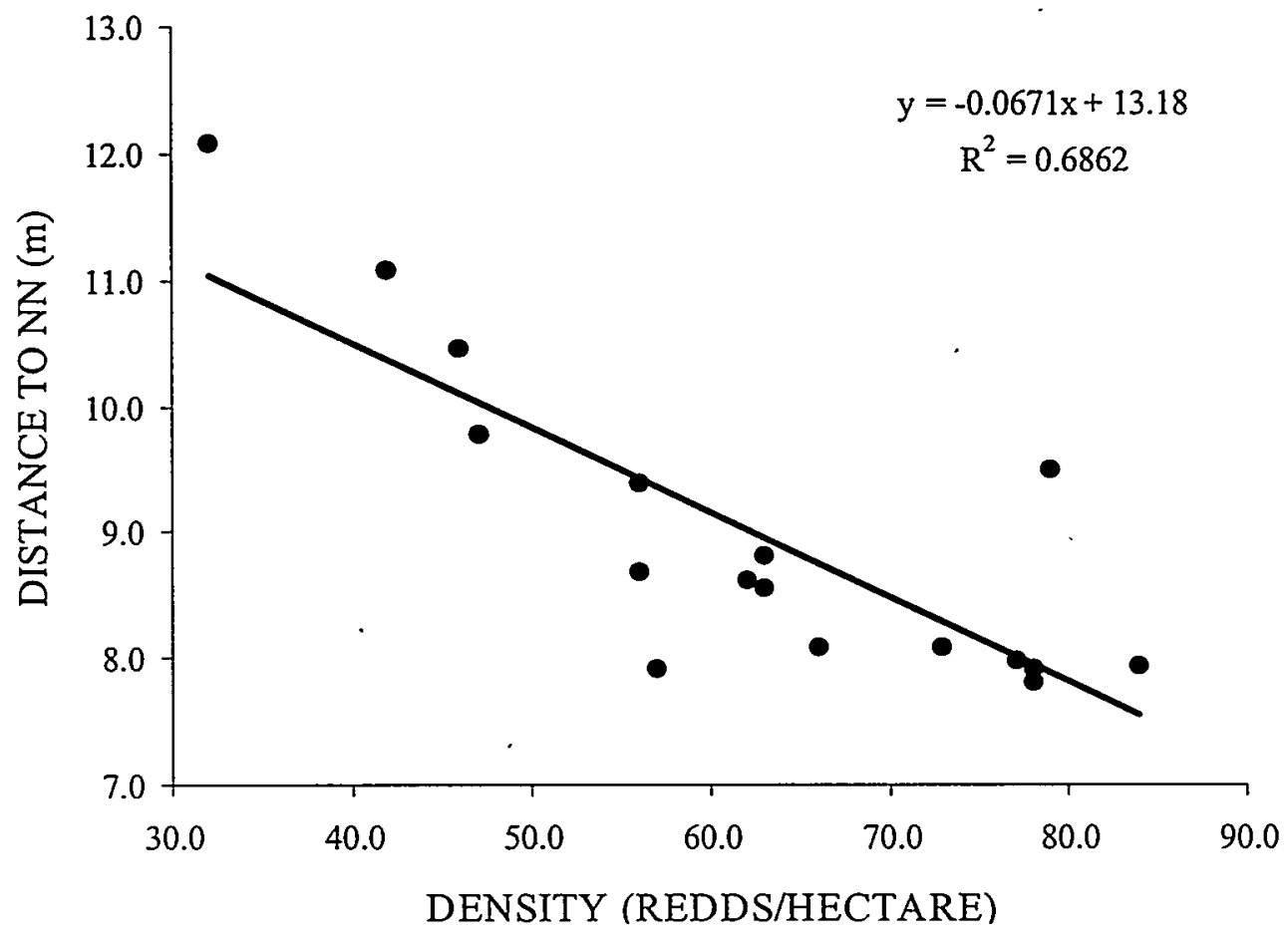

Figure 18. The Relationship Between Redd Density and Distance to Nearest Neighbor Within the Study Site During 1994 and 1995 


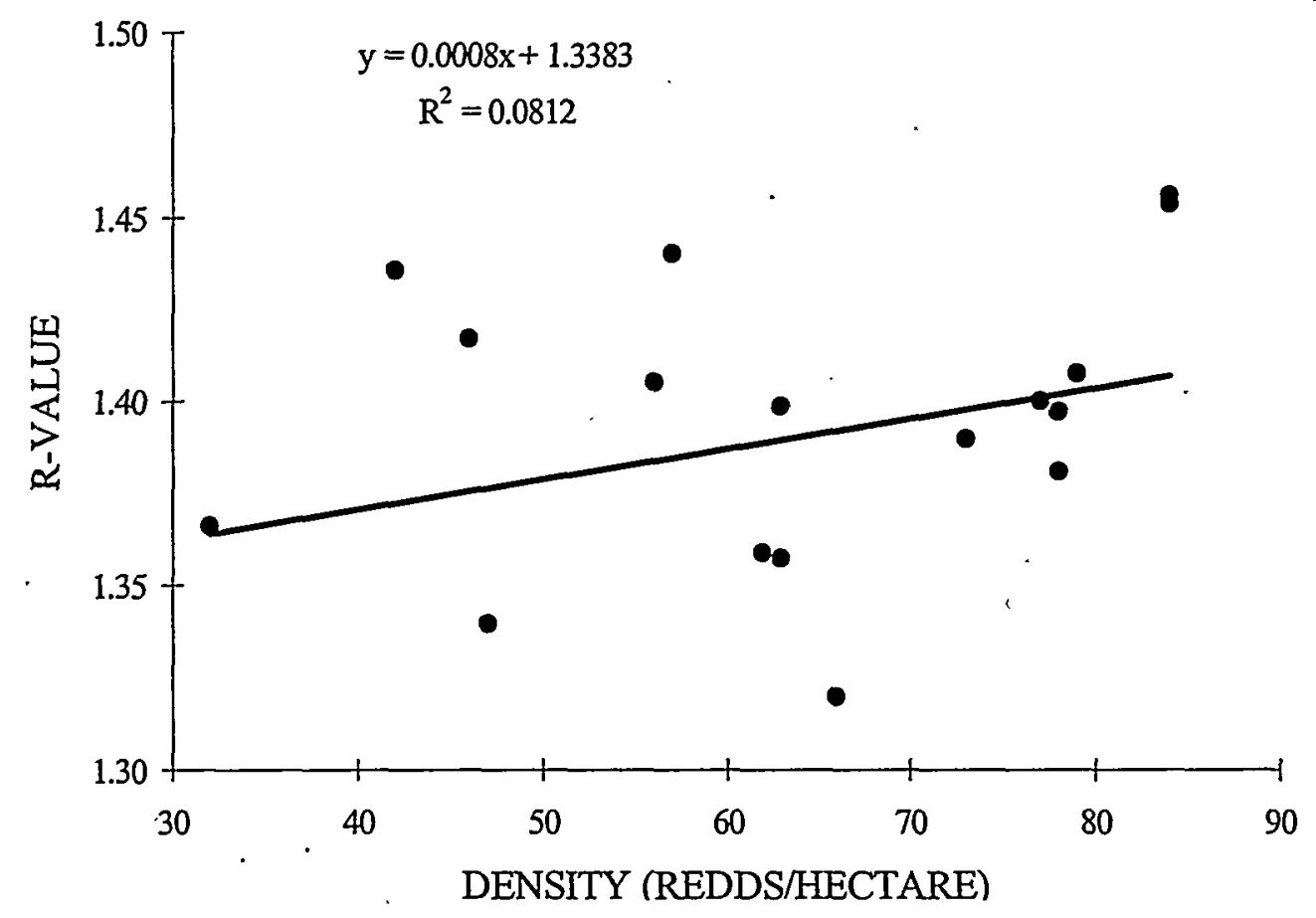

Figure 19. The Relationship Between Redd Density and R-Values Within the Study Site During 1994 and 1995

\subsection{Estimating Spawner Carrying Capacity}

The GIS analyses of the study. site provided a set of metrics that was used to estimate the spawner carrying capacity of the Hanford Reach. The metrics used were considered conservative. Therefore, the estimated carrying capacity may be low, and it is referred to as a minimum carrying capacity. Using the mean redd size $\left(21.2 \mathrm{~m}^{2}\right)$ and the mean inter-redd distance $(2.8 \mathrm{~m})$, estimated area used per redd in 1994 was calculated $\left(91.54 \mathrm{~m}^{2}\right)$. The total cluster area of the study site $\left(871,890 \mathrm{~m}^{2}\right)$ was then divided by the estimated area used per redd to calculate the minimum number of redds to fully seed the habitat within the redd clusters,

$$
871,890 / 91.54=9525
$$

Redds needed to fully seed the study site was divided by the actual number of redds detected with GIS analyses in $1994(6,314)$ to get a conversion factor estimator,

$$
9,525 / 6,314=1.51
$$

The conversion factor estimator was multiplied by estimated escapement $(48,857)$ to calculate a minimum carrying capacity for the Hanford Reach using 1994 spatial relationships,

$$
1.51 \cdot 48,847=73,759
$$


The minimum carrying capacity needed to fully seed the Hanford Reach changes considerably if spatial relationships found in the redd cluster with the highest density are used in the calculations. For example, when the mean redd size was changed to 18.7 squared meters, and the mean inter-redd distance to $2.5 \mathrm{~m}$, the calculation returned a value of 89,408 salmon to fully seed the available habitat.

\subsection{GIS Analyses Versus Aerial Surveys and Dam Counts}

Analysis of the relative proportion of total redds counted for each area showed that the two techniques of monitoring and counting redds exhibited similar patterns for the 3 years studied (Figure 20). Area 5 had the highest proportion of redds counted each year, while Area 3 had the lowest proportion. However, the number of redds counted using aerial photographs and GIS analyses was considerably higher compared to the final redd count of the aerial surveys. In 1994, the redd count within all five areas using GIS analyses was 2.1 times as high as aerial survey redd counts $(8,248$ vs 4,027$)$, and in 1995 , the GIS redd count was 2.7 times the aerial survey count $(5,069$ vs 1,893$)$.

In 1991, when aerial photographs were taken only once (November 11), the total redds counted for all five areas using GIS analyses compared to aerial survey counts (counted on November 10) was very similar. The total redd count using GIS analyses was 2,148 while the aerial survey count was 2,083 . This suggests that the two techniques were similar in their level of accuracy. However, there was a difference in the number of redds counted by the two methods when individual areas were compared (Figure 21). For example, the GIS count for Area 4 was 463 redds, or $27 \%$ higher than the aerial survey count of 365 redds, while the GIS count in Area 3 was 141 redds, or $36 \%$ lower than the aerial survey count of 221 redds.

A comparison between the two redd counts from week to week for 1994 and 1995 showed that early counts were relatively similar (Figure 22), but later in the spawning season, GIS redd counts were substantially higher than aerial survey counts. This divergence seemed to occur as spawning and density of

redds began to increase in the first week of November. When counts for individual areas were compared (Figures 23 and 24), the same divergence appeared in most areas when the number of redds counted ranged from 250 to 300 . However, the number of redds for Area 3 remained less than 400 during both years, and the two techniques returned values that were very similar. In addition to having a lower redd count, Area 3 was smaller in size.

The percentage of redds to female escapement was higher for GIS counts compared to aerial survey counts within the study site for both 1994 and 1995. Using GIS analyses, redd counts within the study site were $23.7 \%$ of the estimated female escapement in 1994 and $21.4 \%$ in 1995 , while the aerial survey counts were only $14.4 \%$ in 1994 and $9.7 \%$ in 1995 (Figure 25). 
a.

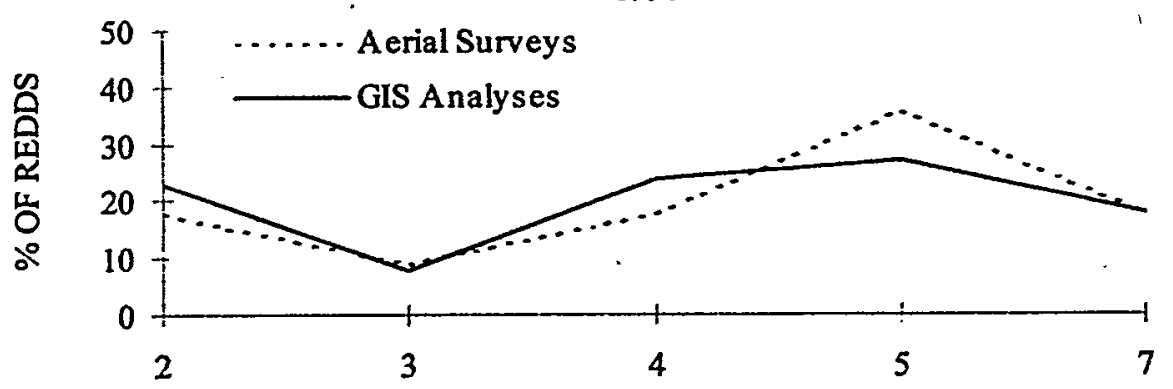

b.

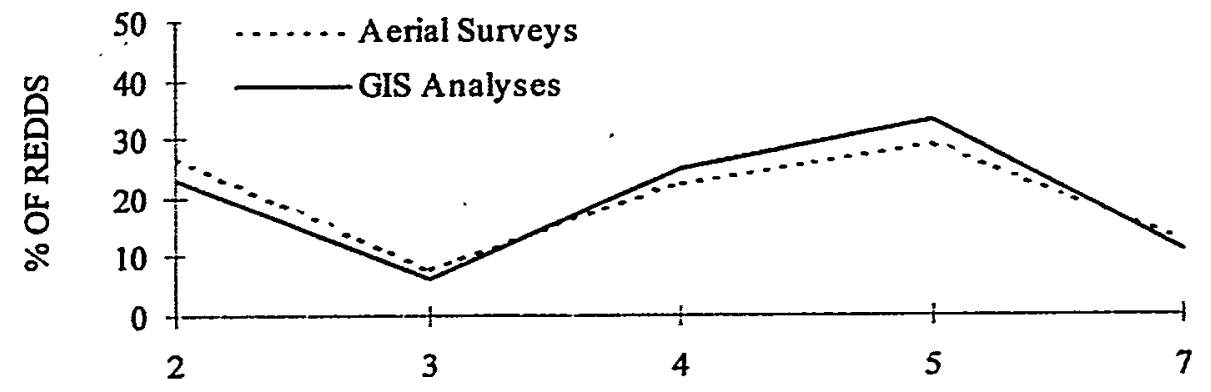

c.

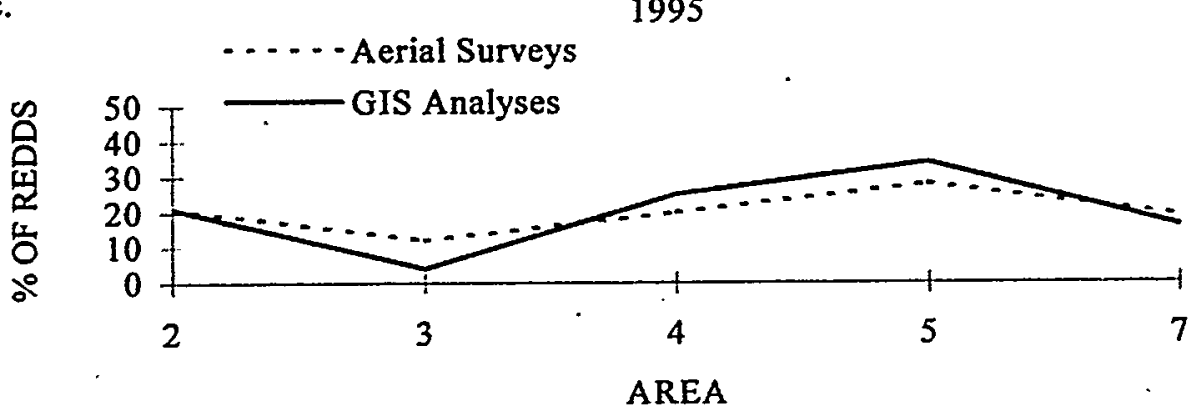

Figure 20. Percentage of Redds that Each Area Contributed to the Total Redd Count in the Study Site for 1991, 1994, and 1995 


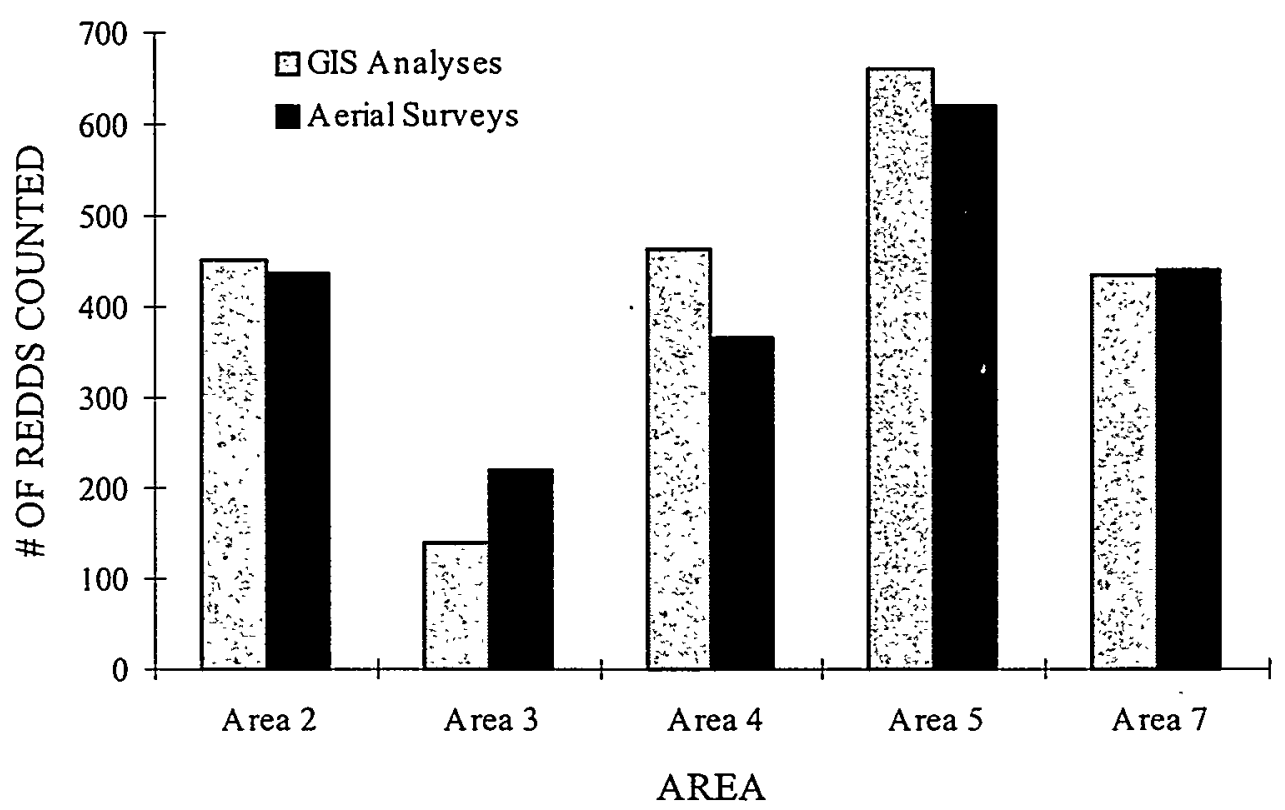

Figure 21. The Number of Redds Counted Per Area in the Hanford Reach During 1991 Using Aerial Photographs with GIS Analyses Versus the Number of Redds Counted Using an Aerial Survey

The percentage of redds counted to female escapement calculated with GIS analyses was less variable than aerial survey counts between the two years. There was a difference of $1.1 \%$ for the GIS calculations compared to a $4.7 \%$ difference for aerial surveys.

\subsection{Identifying Key Index Sites}

Evaluations to identify potential index sites revealed that areas used in conjunction with aerial surveys had a clear point of demarcation in variability between 1994 and 1995 (Table 6). Areas 3 and 7 exhibited relatively low CV of 1.4 and $4.9 \%$, respectively. These two areas exhibited less variability between the two years and reflected female chinook escapement estimates better than Areas 4, 5, and 2, (range of CV from 44.4 to $67.6 \%$ ). In contrast, redd clusters used in GIS analyses did not have a clear point of demarcation among the $\mathrm{CV}$ to isolate clusters that reflected escapement estimates of female chinook (Table 6). However, clusters 5A, 2A, 4B, and 2B appeared to be the most consistent (CV of $15 \%$ or less) at reflecting female returns between the two years. Redd clusters that exhibited the least change between the two years had a wide range in the mean number of redds per cluster (120 to 1302), and a large difference in the size of the sites ( 1.66 to $19.27 \mathrm{ha}$ ). In contrast, the two best index sites for aerial surveys had a narrow range in the mean number of redds (250 to 313) and a small difference in the size of the sites (5.11 to $7.75 \mathrm{ha}$ ). 

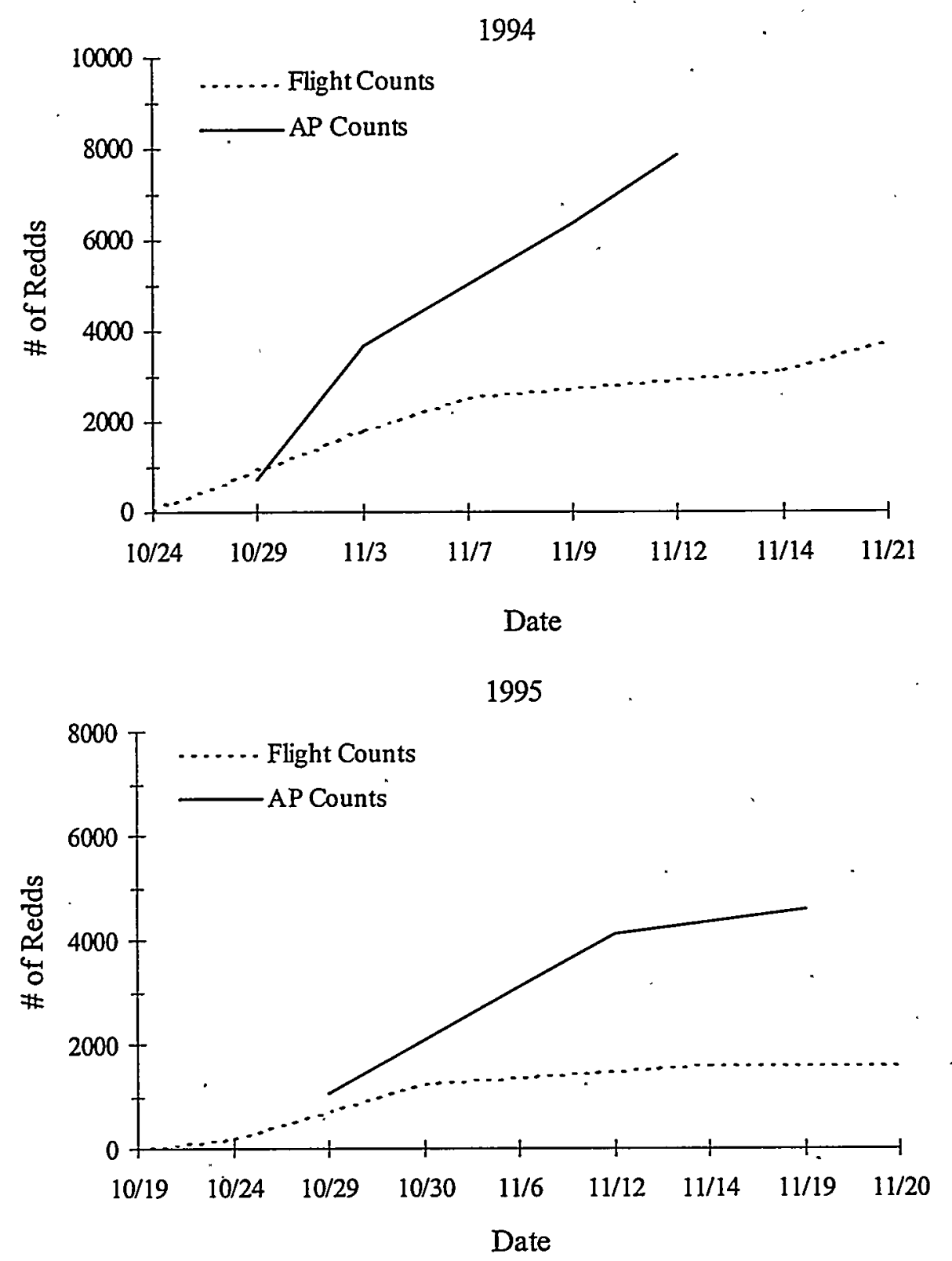

Figure 22. Redd Counts Over Time During 1994 and 1995 Using Aerial Photographs With GIS Analyses and Aerial Surveys in the Hanford Reach Study Site 
1994
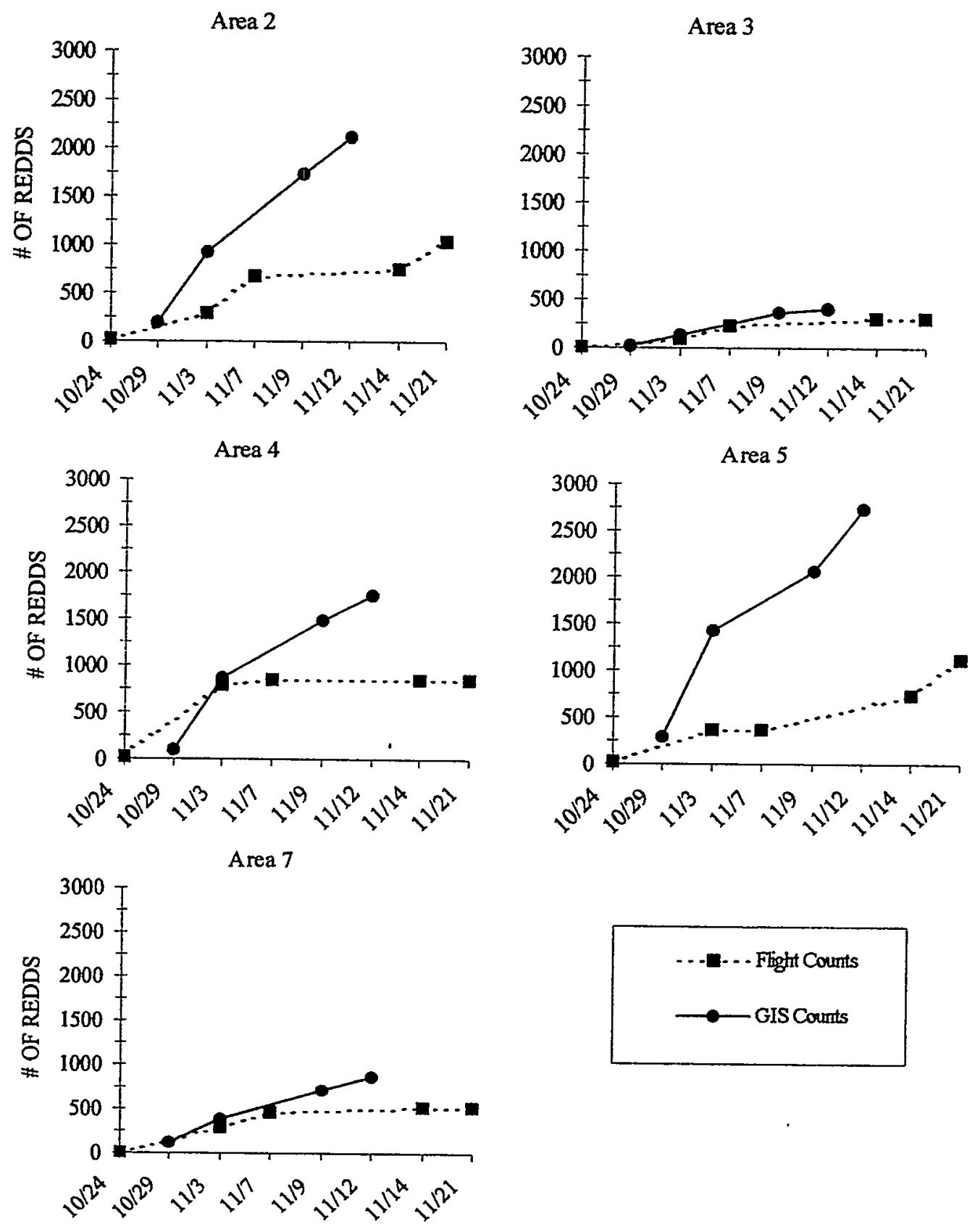

Figure 23. A Comparison Between GIS and Aerial Survey Redd Counts Over Time in Areas 2, 3, 4, 5 , and 7 in the Hanford Reach Study Site During 1994 

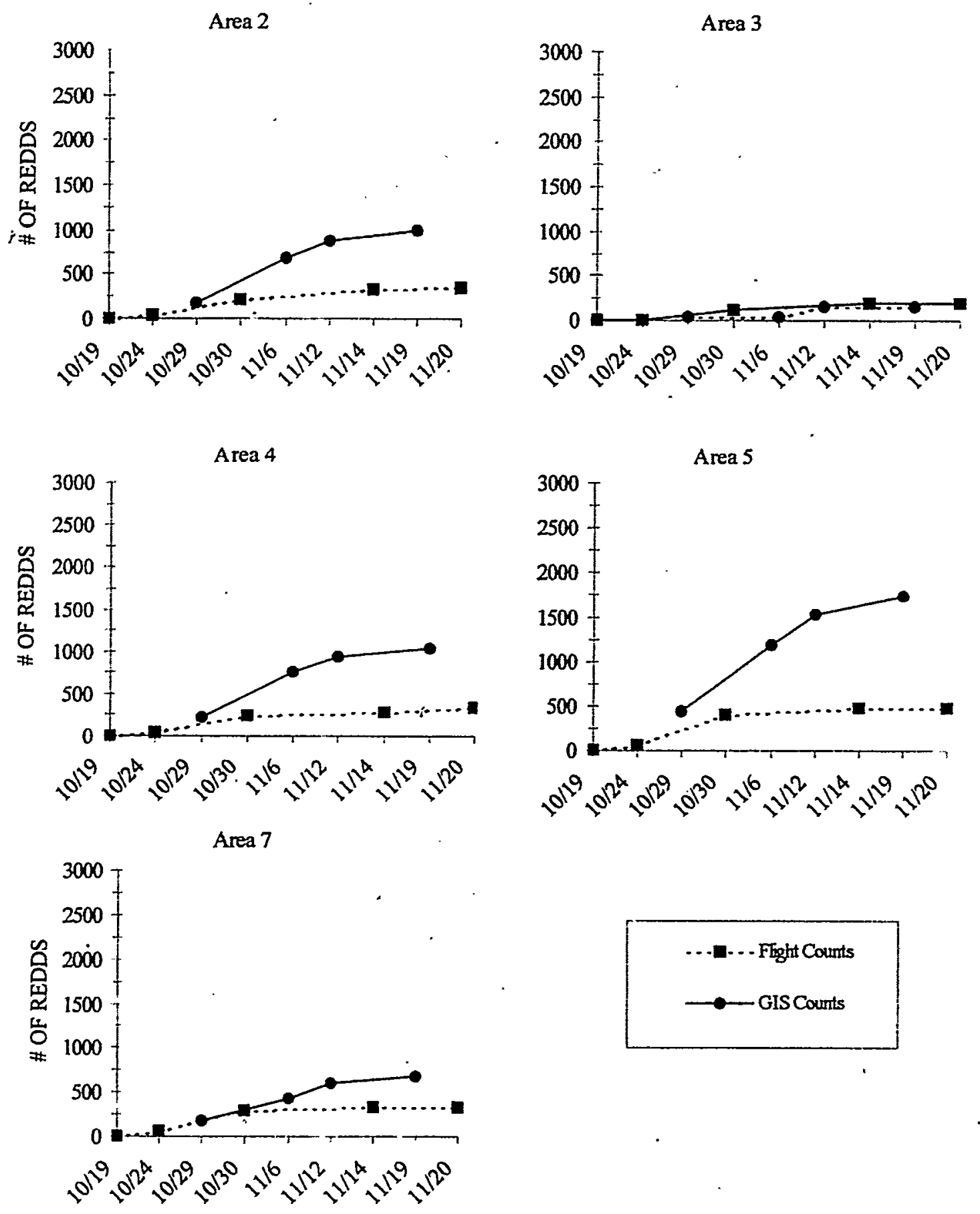

Figure 24. A Comparison Between GIS and Aerial Survey Redd Counts Over Time in Areas 2, 3, 4, 5, and 7 in the Hanford Reach Study Site During 1995 


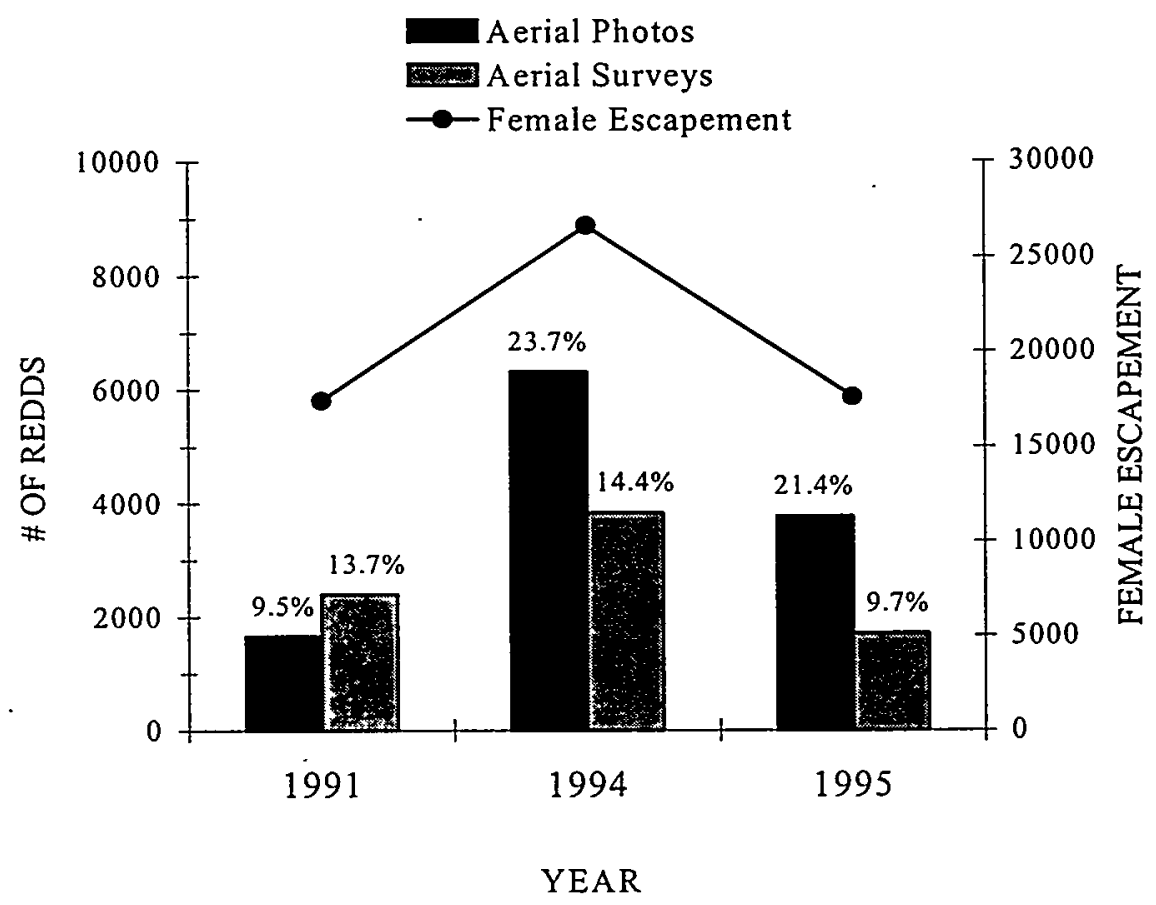

Figure 25. A Comparison Between the Number of Redds Counted With GIS Analyses and Aerial Redd Surveys Within the Hanford Reach Study Site and the Estimated Female Fall Chinook Salmon Escapement into the Hanford Reach for 1991, 1994, and 1995 
Table 6. Number of Redds Counted as a Percentage of the Estimated Female Escapement for Each Area and Redd Cluster With the Coefficient of Variation (CV) Between 1994 and 1995. A lower CV identifies the areas and redd clusters that reflected the estimated female escapement more consistently between the two years.

\begin{tabular}{||c|c|c|c||}
\hline \multirow{2}{*}{ Aerial Survey Areas } & \multicolumn{2}{|c|}{$\begin{array}{c}\text { Number of Redds Counted as a Percentage } \\
\text { of Estimated Female Escapement }\end{array}$} & \multirow{2}{*}{ CV (\%) } \\
\cline { 2 - 4 } & 1994 & 1995 & 1.4 \\
\hline \hline 3 & 1.13 & 1.14 & 4.9 \\
\hline 7 & 1.93 & 1.85 & 44.4 \\
\hline 5 & 4.21 & 2.76 & 52.8 \\
\hline 4 & 3.21 & 1.93 & 67.6 \\
\hline 2 & 3.88 & 2.01 & $\cdot$ \\
\hline
\end{tabular}

\begin{tabular}{|c|c|c|c|}
\hline GIS Analysis Cluster & 1994 & 1995 & CV (\%) \\
\hline \hline $5 \mathrm{~A}$ & 5.88 & 5.90 & 0.5 \\
\hline $2 \mathrm{~A}$ & 3.19 & 3.09 & 3.4 \\
\hline $4 \mathrm{~B}$ & 4.63 & 4.20 & 10.3 \\
\hline $2 \mathrm{~B}$ & 0.57 & 0.49 & 15.3 \\
\hline $4 \mathrm{~A}$ & 1.41 & 1.16 & 20.6 \\
\hline $7 \mathrm{~A}$ & 2.70 & 3.31 & 21.6 \\
\hline $3 \mathrm{~A}$ & 1.50 & 1.12 & 31.1 \\
\hline $5 \mathrm{~B}$ & 2.04 & 1.43 & 37.7 \\
\hline $2 \mathrm{C}$ & 1.79 & 0.89 & 71.6 \\
\hline
\end{tabular}




\subsection{Discussion and Conclusions}

\subsection{Redd Counts, Habitat Identification and Mapping, and Density Measurements}

Monitoring redd abundance with aerial photography and GIS analyses was effective for distinguishing and counting visible redds within the study site. One limitation of using aerial techniques is its inability to detect redds in deep water (i.e., depths greater than $4 \mathrm{~m}$ ). Researchers have found that spawning in water depths greater than $4 \mathrm{~m}$ is common within the Hanford Reach (Swan et al. 1988; Chapman et al. 1994). Daily fluctuations in water surface elevations because of dam operations can be extreme, complicating the process of counting redds using aerial methods. Dauble and Watson (1990) reported that, on average, aerial surveys detected one redd for every nine adults entering the Hanford Reach (i.e., redd-to-adult ratios ranged from 1:3 to 1:16).

In contrast, this study found a relatively constant redd to adult ratio of 1:3.4 in 1994 and 1:3.7 in 1995 (estimated adult escapement was 48,857 in 1994 and 32,288 in 1995). Swan et al. (1988) estimated that . up to $80 \%$ of spawning by fall chinook salmon may occur in water too deep (3-4 $\mathrm{m}$ ) for detection by aerial observation. A $20 \%$ detection rate is relatively low for monitoring purposes. However, data from this study suggested that the proportion of redds detected was not $20 \%$, but approximately $50 \%$ when comparing the number of redds versus estimated female escapement in 1994 and 1995 (estimated female escapement was 26,627 in 1994 and 17,597 in 1995). Therefore, remote sensing with aerial photography in conjunction with GIS technology appears to be more accurate for counting and tracking spawning population trends then previously thought possible using aerial methods.

GIS analyses also provided effective means to map and monitor the location of individual redds and redd clusters in visible habitat and identified changes in habitat use. Locations of redds were mapped with a relatively high degree of precision in relation to other redds, physical features, and survey markers. Analysis of habitat use at different scales may identify the source of a change and potentially increase our knowledge of cause and effect relationships between biological or physical processes and spawning. For example, Geist and Dauble (1998) recently used GIS to evaluate redd site selection and its relationship to geomorphic features and processes at a river-reach scale. This study monitored changes in habitat use at a redd cluster scale, which was made possible by using aerial photography and GIS analyses. Other monitoring techniques currently used cannot map spatial factors to the scale that GIS analyses can. For example, dam counts only map use at a river section scale (dam to dam), and aerial surveys only monitor changes at a defined-area scale. GIS analyses can detect change at many scales ranging from redd clusters to river reaches.

GIS analyses revealed that a few sites at the outer edges of redd clusters were used in 1994 but not in 1995. Identifying these changes in habitat use created some questions: Did a portion of the pre-existing suitable habitat change to unsuitable habitat from 1994 to 1995, or did other factors cause the change in habitat use? If areas of pre-existing habitat were no longer suitable because of some environmental or ecological factor, would continued monitoring of these areas show them to be unused in the future? 
Another possibility is that the higher escapement levels in 1994 increased competition for space, which forced spawning adults to migrate outward from the core spawning area. If this is true and outward migration into sub-optimal spawning habitat occurred, what was the effect on incubation and hatching success in these areas?

GIS mapped data can be used in conjunction with GPS technology in the field to locate and mark varying degrees of spawning use. Once these locations are marked, researchers can study, and possibly differentiate, the physical and biological characteristics between gradients of use. This may identify factors separating quality spawning habitat from sub-optimal and unsuitable habitat. Using GIS and GPS technologies to define and map natural spawning units or quality spawning areas will provide a means to quantify the amount of suitable spawning habitat in the Hanford Reach. These spawning units could prove to be very informative units of analysis for monitoring and studying spawning salmon and for estimating carrying capacity.

The density of redds per river kilometer and per area was higher and proportionally similar for all sites as escapement levels increased. This suggests that these general spatial units had enough spawning habitat to absorb an increased number of spawners and that the increase was evenly distributed among the different segments being monitored (river kilometer or areas). The GIS analyses were effective at measuring use patterns and density. With redds mapped and in digital format, it was a simple process to calculate the number of redds per river kilometer, per survey segment (areas defined by Dauble and Watson 1997), and per ha within redd clusters.

Each unit of analysis (i.e., river kilometers, areas, and redd clusters) has its advantages and disadvantages. River kilometers are constant from year to year and make easy comparisons for trend analysis, but they do not provide the level of detail that other units of measurement provide. Areas described by Dauble and Watson (1990) currently provide the best unit of measurement (redds per area) for historical reference and trend analysis because there are annual records of redds per area for more than 50 years. However, this unit of measurement has no functional link to population level interactions and cannot identify density and spatial characteristic relationships. In contrast to river kilometers and areas, the size of redd clusters changed from year to year even though their core location remained constant. The change in size may make it more difficult to compare year to year figures, although the number of redds found within a cluster and the calculated redds per $m$ are very site specific. Using mapped redd clusters allows chinook salmon to define natural spawning units that are more suitable for monitoring change and researching salmon behavior then segment-based monitoring. Each unit of analysis has a level of usefulness for detecting population trends, monitoring the intensity of habitat use, and increasing our understanding of population dynamics.

When measuring redd density in redds per $\mathrm{m}$, GIS analyses revealed that the maximum spawning density within clusters was 84 redds per $m$ in 1994. Swan (1989) reported redd densities that ranged from 54 to $119 \mathrm{redds} / \mathrm{ha}$ (one site had 119 and all other sites had less than $88 \mathrm{redds} / \mathrm{ha}$ ) with a mean of 65 redds/ha in his five study sites in the Hanford Reach. Only a few occurrences of superimposed redds were detected during 1994 and 1995, which suggests that 84 redds/ha is a density level at which adverse impacts from superimposition are unlikely to occur. It is interesting to note that redd cluster $7 \mathrm{~A}$ reached this upper level of density for both 1994 and 1995 even though escapement levels were considerably 
different between the two years. Perhaps competition for limited habitat and defense of spawning territory at this density forced spawners to search for habitat with less competition. This suggests that $84 \mathrm{redds} / \mathrm{ha}$ may be near the level that superimposition begins. Density for the other redd clusters increased and became more consistent from cluster to cluster in 1994 when escapement levels were higher. This suggests that spawners become more evenly distributed among redd clusters as density increases competition for space.

GIS analyses can be used to monitor habitat changes in location and level of use for at least four reasons. First, changes in population and habitat use can be effectively documented and mapped. Second, mapping the location of redds may delineate quality habitat from sub-optimal or unusable spawning habitat, allowing researchers to examine habitat characteristics and distinguish differences between gradients of use. This research may help to better define natural spawning habitat units and provide insights on other environmental variables influencing spawning habitat selection. Defining and mapping these units will also allow managers to quantify the amount of suitable spawning habitat. Third, if more meaningful spatial units are identified in the future, they can be used to re-evaluate past GIS monitoring data. This re-evaluation may identify trends or relationships that cannot be seen with current units of analyses. Fourth, GIS analyses can be used to calculate a common unit of measurement (i.e., redds per $m$ ) that can be used to evaluate spatial characteristics of redds.

\subsection{Spatial Characteristics and their Relationships to Density and Carrying Capacity}

GIS analyses proved to be useful for measuring redd spatial characteristics. It was predicted that spatial characteristics would change as redd density increased. This was expected, because competition for spawning grounds would force spawners to adjust and to use space more efficiently. Several studies have suggested that relationships between redd density and spatial characteristics may exist, including redd size (Tautz 1977; Neilson and Banford 1983), distance between redds (Horton 1961; Tautz 1977), and spatial distribution of redds (McNeil 1964; Tautz 1977; Neilson and Banford 1983).

The mean redd size measured in this study was slightly larger than measurements taken on the ground reported by Chapman et al. (1986). The difference in redd size may be due to the different methods used to measure redds or to yearly variation in redd size related to different density between years. The relative accuracy of remote sensing (aerial photography) versus measurements taken on the ground is unknown. Some differences in measured redd size are thought to be due to density levels at the time of measurements. Tautz (1977) suggested that there may be a relationship between redd size and redd density and noted the need to evaluate these parameters. Analysis of the data collected for this study revealed a change in average redd size from site to site and year to year, which appeared to be a function of spawner density.

Nearest neighbor analyses suggested that female salmon did not inherently defend a common area around their nest but possibly adjusted the defended area as density increased as a result of competition. Horton (1961) and McNeil (1964) reported that the distance between redds decreased as salmon density increased. If this relationship is accurate, the area disturbed in redd clusters should increase as density increases. The average disturbed area within redd clusters was $15 \%$ in 1994 . This value compares to an 
average of $22 \%$ reported by Swan (1989) in 1986 when escapement was approximately $50 \%$ higher. A comparison between 1994 and 1995 data from this study revealed a similar pattern. There was a 33\% decrease in escapement in 1995 , which equated to a $4 \%$ decrease in disturbed area. Both the change in the distance between redds and the percentage of habitat used suggested that space use changed as density and competition increased or decreased.

Superimposition may occur if redd density and disturbed area continue to increase. Both Horton (1961) and McNeil (1964) found redd superimposition increased in frequency as salmon density on spawning grounds increased. Studies by Swan (1989), Dauble and Watson (1990), and Chapman et al. (1994) have also reported areas of superimposition where redd density was high. Superimposition was not observed often in the study site during 1994 and 1995, possibly because escapement levels were low. For example, escapement levels were 48,857 and 32,288 in 1994 and 1995, respectively, while Swan's work was done in 1986 when escapement was approximately 72,560 .

Monitoring with GIS detected a change in the pattern of redd distribution early in the spawning season. A uniform pattern, or even distribution, of individuals in a population usually results from intraspecific competition, such as defense of a territory (Smith 1992). Neilson and Banford (1983) suggest that site selection and redd distribution patterns of chinook salmon are influenced by interactions between neighboring females. Results from this study showed that the distribution of redds within redd clusters was aggregate or randomly distributed during the first week of spawning, but distribution changed to an evenly spaced pattern as density increased. An explanation for this shift might be that early arriving spawners used habitat that provided the best spawning characteristics. As the number of spawners and their densities increased, competition for the best sites increased and caused spawners to spread out over the remaining habitat.

Redd spatial characteristics and habitat use changed as adult escapement and spawner density increased. Relationships between increased density and spatial variables included a potential decrease in mean redd size, a decrease in nearest neighbor distance, and an even distribution of redds. These patterns of spatial use and density relationships demonstrate that competition may have been a primary cause of changing redd characteristics and distribution patterns found on spawning grounds at 1994 and 1995 escapement levels. Monitoring these spatial characteristics will play a critical role in increasing our understanding of density dependent relationships, particularly those that may affect spawner carrying capacity within available spawning habitat in the Hanford Reach.

Using the average spatial relationships found in all redd clusters and those found in the redd cluster with the highest density, carrying capacity of spawning habitat in the Hanford Reach was estimated to be between 74,000 and 90,000 adult fall chinook. However, higher returns than those found in 1994 may increase competition for space, causing a change in habitat use and spatial relationships, which may equate into more redds fitting into available spawning habitat. In other words, an increased number of spawners and increased redd density could cause a further reduction in redd size and inter-redd spacing and may alter spatial distribution of redds within redd clusters without reducing the viability of eggs 
spawned. Consequently, this study's estimated range of spawner carrying capacity $(74,000$ to 90,000$)$ may need to be adjusted if future research finds that higher escapement translates into more efficient use of available spawning habitat.

Other attempts to estimate carrying capacity of spawning grounds have used at least two spatial measurements in conjunction with spawning habitat area. To estimate carrying capacity, available habitat has been divided by average redd size (Bartholow et al. 1993) and the size of territory a female defends (Burner 1951). Estimating carrying capacity with these methods assumes that spatial characteristics remain static. However, results from this study suggest that spatial variables do not remain static but change as density increases. Therefore, managers must consider cause-and-effect relationships when estimating carrying capacity. Methods that monitor changes in density-driven variables within concentrated spawning sites must be sought and used to fully understand carrying capacity and how to measure it.

Allowing escapement to meet the estimated carrying capacity of the habitat should be the ultimate goal of fisheries managers if they wish to obtain the full production capabilities of the spawning grounds in the Hanford Reach. Currently, the escapement target is 45,000 adults (WDFW and ODFW 1992), which is only $50 \%$ of this study's highest estimated carrying capacity (escapement levels have been higher than 45,000 in recent years). Thus, a dramatic increase in the escapement target may be needed to fully seed available habitat. However, it should be noted that the calculation used to estimate spawner carrying capacity of the Hanford Reach was based on limited data of spatial relationships that were observed in the study site.

Results revealed that the concept of carrying capacity is much more dynamic than simple equations that divide the amount of spawning habitat by average redd size or average spawner territory. Researchers need to monitor spatial characteristics and relationships at densities where spawning activities become disrupted, or at several densities ranging from high to low, so a model can be developed to estimate a point of reduced spawning success. Geologic Information System monitoring and analyses may provide both the means to measure spatial needs for successful spawning and to identify and measure the amount of suitable spawning habitat in the Hanford Reach.

\subsection{GIS Analyses Compared to Aerial Surveys and Dam Counts}

Dam counts, aerial surveys, and GIS analyses all have limitations and biases in their ability to estimate spawning escapement. To evaluate these techniques, a comparison of each of their limitations and biases within three broad categories was made: errors associated with biological behavior and prespawning mortality, human error or limitations, and errors associated with factors that limit visibility.

Wandering occurs when a fish enters a non-natal stream and later attempts to get back on course by swimming downstream or upstream searching for its spawning grounds (this is different from straying, which occurs when a fish spawns in a non-natal stream). Several studies have documented wandering behavior (Meekin 1967; Mendel et al. 1992). Wandering salmon commonly fall back over dams after passing upstream through the fish ladders. During fall back, death can occur as a salmon attempts to pass over a spillway, through a turbine, or through the passage facilities. Wagner and Hillson (1992) found 
that among those that fall back 26 to $52 \%$ of chinook salmon were injured and $1.9 \%$ died. Not only do some salmon fall back while wandering, but a proportion of them will return upstream and pass over the same dam and be counted multiple times (Mendel et al. 1992).

Pre-spawning mortalities are deaths that occur before salmon spawn and can be due to tissue damage (caused by predators, nets, or passage obstructions) and subsequent infection, disease, or just energy exhaustion. Chapman et al. (1994) reviewed pre-spawning mortality and estimated summer and fall chinook pre-spawning mortality to be as high as 30 to $40 \%$ in the upper Columbia River. Bjornn (in Chapmen et al. 1994) estimated pre-spawning loss in the Snake River to be approximately $45 \%$ for spring and summer chinook when only Ice Harbor Dam was present and $55 \%$ after the completion of four other dams on the Snake River. Counting fish more than once, fish that die falling back over dams, or fish that die before they spawn overestimates actual escapement to spawning grounds and affects the redd to adult ratio.

Aerial surveys and GIS analyses each may overestimate the number of spawners because of two spawning behaviors: females that construct test digs, or false redds, and females that construct and deposit eggs in more than one redd. Sometimes a female will start a test dig in which she will not deposit eggs. Many of these false redds are small in size and not identified or counted as redds. Another salmonid spawning behavior that may cause an error is construction of more than one redd by a single female. However, this is unlikely for chinook salmon. Hawke (1978) reported that only one redd was constructed per female chinook, and Burner (1951) reported that after construction of their nests, chinook stayed and defended their redds until they exhausted their energy reserves or died. Females that construct false redds or construct more than one redd may cause redd counts to misrepresent the number of successful spawning females. However, these behaviors probably have a minimal impact on the overall effectiveness of monitoring techniques using aerial surveys or GIS analyses.

Human error or limitations can be found in all three monitoring techniques. Counting errors occur at dams when fish are misidentified, are counted more than once, or are not counted at all as they pass the viewing station (reviewed in Dauble and Mueller 1993). A source of human error for aerial surveys is the inability of the observer to count all redds in the time it takes to fly over the area being surveyed. As the number and density of redds increase, it becomes more difficult to distinguish the number of individual redds. The observer is forced to make estimates that can lead to more uncertainty. GIS analyses can miscount the number of redds if redds are digitized more than once or if natural structures (e.g., lightcolored clay patches) are identified as redds.

Factors limiting the visibility of fish and redds can also impact all three monitoring techniques. Visibility limitations can be attributed to physical and human-controlled factors. Physical factors can play a large role in reducing redd visibility during aerial surveys and on aerial photographs. They include water turbidity, river flow or elevation, cloud cover, surface winds, and angle and intensity of sunlight (Dauble and Watson 1990). Human-controlled factors that affect the visibility of redds include height, speed, and orientation of the plane, as well as the type of film and equipment used for aerial photographs. Setting standards for equipment and plane operations and planning for optimal viewing conditions can ameliorate many of these factors. The largest potential error for aerial surveys and GIS analyses is due to deep-water spawning. Redds that are deposited in water depths greater than $4 \mathrm{~m}$ are usually not visible 
using aerial methods. As stated earlier, Swan et al. (1988) estimated that only $20 \%$ of redds in the Hanford Reach are visible by aerial means. However, this study suggests that this estimate is too low, and up to $50 \%$ of the redds were visible by aerial means in 1994 and 1995 . The discussion about the biases and limitations of each monitoring technique provides the background needed to evaluate the accuracy of GIS analyses and aerial surveys.

Geological Information System analyses counted twice as many redds as aerial surveys within the study site for both 1994 and 1995. Geological Information System analyses of the study site accounted for 21 to $24 \%$ of the estimated number of females spawning in the Hanford Reach during these two years, while aerial surveys accounted for 10 to $14 \%$. This large difference was a concern, because past studies reported that aerial surveys were highly correlated with estimated escapement $\left(r^{2}=0.79\right.$, Dauble and Watson 1990). So evaluations were conducted to explain the difference.

Evaluations of the data from 1991 showed that GIS analyses and aerial surveys provided similar total redd counts for all areas combined, but some individual areas were substantially different. Week by week comparisons during 1994 and 1995 of the whole study site revealed that the difference between redd counts became larger as time passed. Similar comparisons of individual areas revealed the same pattern of divergence over time for all areas except those that were small in size and had less than 400 redds. This indicated that the size of the area and the density of redds within the area, a.variable that changed as time passed, influenced the number of redds counted using these monitoring techniques.

A possible explanation for the two different redd counts may be the counting methods used. When the number and density of redds increased, it became more difficult to identify and count individual redds during aerial surveys, so some estimates were made (Dauble and Watson 1990). These estimates appeared to be low in some cases in 1991 and may be a factor in underestimating the number of redds over time. In contrast, GIS analyses had some choice of viewing conditions (by selecting the best photographs to detect redds), used cumulative information from previous weeks, and did not have time restrictions. As densities increased, there was sufficient time to make sure that each redd on the photograph was mapped and counted. One other difference between the two techniques occurred during the digitizing of redds for GIS analyses. Redds were added in locations where none were marked before (i.e., a cumulative count) to determine the total count for the year, while aerial surveys used the highest count of the season for the final redd count. If viewing conditions were poor during the last fly over of the year (when maximum numbers of redds are usually present), redds may have been missed that were previously counted. However, GIS analyses had a record of these redds and counted them along with any additional redds that may have been detected for the first time.

As stated earlier, monitoring fall chinook spawning using GIS analyses has several other advantages over aerial surveys besides counting accuracy. In the Hanford Reach, GIS technology can analyze redds and spawning habitat at different spatial scales than can be accomplished by aerial surveys. GIS analyses map specific redd locations within defined redd clusters (habitat use), while aerial surveys place redds in general locations (defined areas). More accurate mapping of redd locations and spawning areas can be used to study and define characteristics of spawning habitat, measure the quantity of spawning habitat, and identify smaller scale changes in habitat use over time. GIS analyses can calculate redd density within used habitat, measure spatial characteristics associated with redds, and identify density spatial 
relationships. GIS analyses can change units of analysis easily, and historical GIS data can be reevaluated in the context of the newly defined units, whereas aerial survey data cannot. These strengths make GIS analyses a viable option to consider for monitoring fall chinook spawning.

\subsection{Identifying Key Index Sites}

Index sites are useful when the total population cannot be counted or monitored because of money, labor, or time limitations. The usefulness of a particular index site depends on how consistently it reflects the population during years of dramatic change in population size. In addition, Irvine et al. (1992) found that the success of an index site to estimate escapement is dependent on how well it reflects distribution of fish in the river. However, the usefulness of a particular site that meets these qualifications may change over time if habitat or other environmental conditions change. If a chosen index site has a bias, escapement estimates may be skewed, resulting in ill-informed management actions.

Evaluations revealed two aerial survey areas (i.e., Areas 3 and 7) that reflected estimated escapement better than the other areas studied. These two sites had the least number of redds counted within their boundaries, and they were also the smallest in area. In contrast, evaluations of redd clusters using GIS analyses did not have a clear point of separation that distinguished the best index sites. Clusters 5A, 2A, $4 \mathrm{~B}$, and $2 \mathrm{~B}$ were generally the better reflectors of escapement estimates and were considered the best index sites in relative terms. Evaluations also revealed that the redd clusters identified by GIS analyses as the best index sites exhibited a wide range in the number of redds observed in them and in the area that they covered compared to the best index sites identified using aerial surveys. To avoid biases because of size or density-dependent factors, index sites should encompass a range of physical size and redd numbers. Conversely, sites that are chosen with little variation in their size or in the number of redds within them may not perform well through the range of escapement levels. For example, smaller sites may fill up with spawners quickly when population returns are high, requiring spawning adults to use areas with more spawning ground and less competition.

Use of index sites may reduce sampling effort, saving both money and time. However, managers should always keep in mind that index sites may not reflect a problem or a change associated with a proportion of the population outside of the chosen index sites. Therefore, if personnel, money, and time are available, all spawning sites should be monitored.

\subsection{Conclusion}

GIS analyses of aerial photographs identified and accounted for more redds than other monitoring techniques in the Hanford Reach and accounted for approximately $50 \%$ of the estimated escapement. Results from GIS analyses revealed that, as density increased, the mean redd size decreased, the distance between nearest neighbors decreased, and the spatial patterns of redds within redd clusters changed to a more even distribution. Based on these spatial parameters and density relationships, the spawner carrying capacity in the Hanford Reach for fall chinook salmon may be as high as 74,000 to 90,000 , which is substantially higher than the current escapement goal of 45,000 . Index site evaluations revealed that Areas 3 and 7 were the best index sites for aerial surveys, while redd clusters $5 \mathrm{~A}, 2 \mathrm{~A}, 4 \mathrm{~B}$, and $2 \mathrm{~B}$ were the best index sites using aerial photography and GIS analyses. 
Each monitoring technique has its own advantages (Table 7). Using dam passage counts with adjustments for fallback may be the best technique for estimating adult escapement, but several factors (e.g., pre-spawning mortality) affect the number of successful spawners. Aerial surveys, which may be the least expensive, provide a means of counting redds, mapping general spawning locations, detecting large-scale changes in habitat use, and recording temporal information about spawning. GIS analyses have a relatively high accuracy for counting redds, mapping habitat, measuring density and redd characteristics, performing spatial analyses, and providing a digital record to conduct historical reviews if new information becomes available. Clearly, monitoring with GIS technology will provide quality and quantifiable data. These data will support and add to information provided by aerial surveys and escapement estimates, which is needed to successfully monitor and study fall chinook salmon spawning in the Hanford Reach of the Columbia River.

Table 7. A Comparison and Contrast of Relative Monitoring Capabilities of Each Technique. $(\mathrm{H}=$ high, $\mathrm{M}=$ medium, $\mathrm{L}=$ low, and $\mathrm{N}=$ none. $)$

\begin{tabular}{||l|c|c|c||}
\hline \multicolumn{1}{|c|}{ Monitoring Capabilities and Costs } & Escapement Estimates & Aerial Surveys & GIS Analyses \\
\hline \hline Accuracy of adult counts & $\mathrm{H}$ & $\mathrm{L} / \mathrm{M}$ & $\mathrm{M}$ \\
\hline Accuracy of redd counts & $\mathrm{N}$ & $\mathrm{M}$ & $\mathrm{H}$ \\
\hline Habitat mapping & $\mathrm{N}$ & $\mathrm{M}$ & $\mathrm{H}$ \\
\hline Spatial analysis in the Hanford Reach & $\mathrm{N}$ & $\mathrm{L}$ & $\mathrm{H}$ \\
\hline Spatial analysis in redd clusters & $\mathrm{N}$ & $\mathrm{N}$ & $\mathrm{H}$ \\
\hline Historical reviews with new data & $\mathrm{N} / \mathrm{L}$ & $\mathrm{N} / \mathrm{L}$ & $\mathrm{H}$ \\
\hline Relative costs & $\mathrm{H}$ & $\mathrm{L}$ & $\mathrm{M}$ \\
\hline
\end{tabular}




\subsection{References}

Bartholow JM, JL Lakke, CB Stalnaker, and SC Williamson. 1993. "A salmonid population model with emphasis on habitat limitations." River 4(4):265-279.

Burner CJ. 1951. "Characteristics of spawning nests of Columbia River salmon." U.S. Fish and Wildlife Service Fishery Bulletin 52:97-110.

Chapman WM. 1943. "The spawning of chinook salmon in the main Columbia River." Copeia 3:168170.

Chapman D, A Giorgi, T Hillman, D Deppert, M Ehro, S Hays, C Peven, B Suzumoto, and R Klinge. 1994. Status of summer/fall chinook salmon in the Mid-Columbia Region. Don Chapman Consultants, Boise, Idaho.

Chapman DW, DE Weitkamp, TL Welsh, MB Dell, and TH Schadt. 1986. "Effects of river flow on the distribution of chinook salmon redds." Transactions of the American Fisheries Society 115:537-547.

Chapman DW, DE Weitkamp, TL Welsh, and TH Schadt. 1983. Effects of minimum flow regimes on fall chinook spawning at Vernita Bar 1978-1982. Report prepared for Grant County Public Utility District by Don Chapman Consultants, McCall, Idaho, and Parametrix, Inc., Bellevue, Washington.

Clark PJ, and FC Evans. 1954. "Distance to nearest neighbor as a measure of spatial relationships in populations." Ecology 35(4):445-450.

Conner WP, AP Garcia, HL Burge, and RH Taylor. 1993. "Fall chinook salmon spawning in freeflowing reaches of the Snake River." Pages 1-29 in DW Rondorf and WH Miller (eds). Identification of the spawning, rearing, and migratory requirements of fall chinook salmon in the Columbia River basin. U.S. Department of Energy, Bonneville Power Administration, Portland, Oregon.

Dauble DD, and DG Watson. 1997. "Status of fall chinook populations in the Mid-Columbia River, 1948-1992." North American Journal of Fisheries Management 17(2):283-300.

Dauble DD, and RP Mueller. 1993. Factors, affecting the survival of upstream migrant adult salmonids in the Columbia River Basin. Recovery issues for threatened and endangered Snake River salmon technical report 9 of 11. Report prepared for the Boneville Power Administration by Pacific Northwest Laboratory, Richland, Washington.

Dauble DD, and DG Watson. 1990. Spawning and abundance of fall chinook salmon (Oncorhynchus tshawytscha) in the Hanford Reach of the Columbia-River, 1948-1988. PNL-7289, Pacific Northwest Laboratory, Richland, Washington. 
Dauble DD, RL Johnson, RP Mueller, and CS Abernethy. 1995. Spawning of fall chinook salmon downstream of lower Snake River hydroelectric projects, 1994. Report to the U.S. Army Corps of Engineers, Walla Walla District, Walla Walla, Washington.

Dirkes RL, RW Hanf, and TM Poston (eds.). 1999. Hanford Site Environmental Report for Calendar Year 1998. PNNL-12088, Pacific Northwest National Laboratory, Richland, Washington.

Dresel PE, PD Thorne, SP Luttrell, BM Gillespie, WD Webber, JK Merz, JT Rieger, MA Chamness, SK Wurstner, and BE Opitz. 1995. Hanford Site groundwater monitoring for 1994. PNL-10698, Pacific Northwest Laboratory, Richland, Washington.

Fitzner RF, and RH Gray. 1991. "The status, distribution and ecology of wildlife on the U.S. DOE Hanford Site: A historical overview of research activities." Environmental Monitoring and Assessment 18:173-202.

Forman RT, and M Godron. 1986. Landscape Ecology. John Wiley \& Sons, New York.

Geist DR, and DD Dauble. 1998. "Redd site selection and spawning habitat use by fall chinook salmon: The importance of geomorphic features in large rivers." Environmental Management 22:655-669.

Geist DR, DD Dauble, and RH Visser. 1997. The development of a spawning habitat model to aid in recovery plans for Snake River fall chinook salmon. U.S. Department of Energy, Bonneville Power Administration, Portland, Oregon.

Giorgi AE. 1992. Fall chinook salmon spawning in Rocky Reach Pool: Effects of a three foot increase in pool elevation. Report prepared for Chelan County Public Utility District by Don Chapman Consultants, Redmond, Washington.

Hawke SP. 1978. "Stranded redds of quinnat salmon in the Mathias River, South Island, New Zealand." New Zealand Journal of Marine and Freshwater Research 12:167-171.

Horton PA. 1961. "The bionomics of brown trout in a Dartmoor stream." Journal of Animal Ecology 30:311-338.

Huntington CS, W Nehlsen, and J Bowers. 1996. "A survey of healthy native stocks of anadromous salmonids in the Pacific Northwest and California." Fisheries 21(3):6-14.

ISG (Independent Scientific Group). 1996. Return to the river, restoration of salmonid fishes in the Columbia River ecosystem. Northwest Power Planning Council, Portland, Oregon.

Irvine JR, RC Bocking, KK English, and M Labelle. 1992. "Estimating coho salmon (Oncorhynchus kisutch) spawning escapements by conducting visual surveys in areas selected using stratified random and stratified index sampling designs." Canadian Journal of Fisheries and Aquatic Sciences 49:1972-1981. 
Lunetta RS, BL Cosentino, DR Montgomery, EM Beamer, and TJ Beechie. 1997. "GIS-based evaluation of salmon habitat in the Pacific Northwest." Photogrammetric Engineering \& Remote Sensing 63:(10)1219-1229.

McNeil WJ. 1964. "Redd superimposition and egg capacity of pink salmon spawning beds." Journal of Fisheries Research Board of Canada 21:1385-1396.

Meekin TK. 1967. Report of the 1996 Wells Dam chinook tagging study. Washington Department of Fisheries. Report to Douglas County Public Utility District, Ephrata, Washington.

Mendel G, D Milks, M Clizer, and R Bugert. 1992. "Upstream passage and spawning of fall chinook salmon in the Snake River." In: HL Blankenship and GW Mendel (eds.), Upstream passage, spawning, and stock identification of fall chinook salmon in the Snake River, 1992. Annual Report FY 92-93. Report to the Bonneville Power Administration, Portland, Oregon.

Milhous RT. 1979. "The PHABSIM system for instream flow studies." In: Proceedings of the 1979 summer computer simulation conference, Society for Computer Simulation, Toronto, Ontario.

Neilson JD, and CE Banford. 1983. "Chinook salmon (Oncorhynchyus tshawytscha) spawner characteristics in relation to redd physical features." Canadian Journal of Zoology 61:1524-1531.

Rickard WH, and LD Poole. 1989. "Terrestrial wildlife of the Hanford Site: Past and future." Northwest Science 63(4):183-193.

Schuster RL, and WH Hays. 1984. Irrigation-induced landslides in soft rocks and sediments along the Columbia River, south-central Washington state, U.S.A. In: Proceedings of the $4^{\text {th }}$.international symposium on landslides 1:431-436, Toronto, Canada.

Smith RL. 1992. Elements of ecology. $3^{\text {rd }}$ ed, HarperCollins, New York.

Stalnaker CB. 1979. "The use of habitat preferenda for establishing flow regimes necessary for maintenance of fish habitat." Pages 321-337 in JV Ward and JA Stanford (eds.). The ecology of regulated streams. Plenum Publishing, New York.

Swan GA. 1989. "Chinook salmon spawning surveys in deep waters of a large, regulated river." Regulated Rivers: Research \& Management 4:355-370.

Swan GA, EM Dawley, RD Ledgerwood, WT Norman, WF Cobb, and DT Hartman. 1988. Distribution and relative abundance of deep-water redds for spawning fall chinook salmon at selected study sites in the Hanford Reach of the Columbia River. National Oceanic and Atmospheric Administration, National Marine Fisheries Service, Seattle, Washington.

Tautz AF. 1977. Effects of variability in space and time on the production dynamics of salmonid fishes. Ph.D. dissertation, University of British Columbia, Vancouver. 
USACE (US Army Corps of Engineers). 1995. Final environmental impact statement, Columbia River system operation review. USACE, Portland, Oregon.

WDFW and ODFW (Washington Department of Fish and Wildlife and Oregon Department of Fish and Wildlife). 1992. Status report Columbia River fish runs and fisheries 1938-1993. WDFW, Olympia, Washington.

Wagner P, and T Hillson. 1992. 1991 evaluation of adult fallback through the McNary Dam juvenile bypass system. Washington Department of Fisheries Report to U.S. Army Corps of Engineers, Seattle, Washington. 


\section{Distribution}

No. of

Copies

\section{OFFSITE}

Dale Bambrick

Washington Department of Fish and Wildlife

1701 South $24^{\text {th }}$ Avenue

Yakima, WA 98902-5720

William Connor

U.S. Fish and Wildlife Service

P.O. Box 18

Ahsahra, ID 83520

Debbie Docherty

Bonneville Power Administration

P.O. Box 3621

Portland, OR 97208

Aaron Garcia

U.S. Fish and Wildlife Service

P.O. Box 18 .

Ahsahra, ID 83520

Philip Groves

Idaho Power Company

P.O. Box 70

Boise, ID 83707

Joe Hymer

Washington Department of Fish

and Wildlife

2108 Grand Boulevard

Vancouver, WA 98661

$5 \quad$ Richard Visser

41 Summit Drive

Grandview, WA 98930
No. of

Copies

Paul Wagner

Washington Department of Fish

and Wildlife

500 N Morain Suite 1200B

Kennewick, WA 99336

\section{ONSITE}

\section{DOE Richland Operations Office}

D.W. Lloyd

A5-15

D.C. Ward

A5-15

26 Pacific Northwest National Laboratory

D.D. Dauble (5)

K6-85

R.L. Dirkes

K6-75

C.A. Duberstien

$\mathrm{K} 6-85$

L.L. Cadwell

K6-85

R.M. Ecker

D.R. Geist (5)

SEQUIM

K6-85

R.P. Mueller

K6-85

T. M. Poston

K6-75

D.C. Stapp

$\mathrm{K} 6-75$

G. A. McMichael

K6-85

T. P. Hanrahan

K6-85

Information Release (7)

Distr. 1 